Invited review

\title{
BDNF-induced local protein synthesis and synaptic plasticity
}

\author{
Graciano Leal $^{\mathrm{a}, \mathrm{b}, 1}$, Diogo Comprido ${ }^{\mathrm{a}, 1}$, Carlos B. Duarte ${ }^{\mathrm{a}, \mathrm{b}, *}$ \\ ${ }^{a}$ CNC-Center for Neuroscience and Cell Biology, University of Coimbra, 3004-517 Coimbra, Portugal \\ ${ }^{\mathrm{b}}$ Department of Life Sciences, University of Coimbra, 3004-517 Coimbra, Portugal
}

\section{A R T I C L E I N F O}

\section{Article history:}

Received 2 February 2013

Received in revised form

25 March 2013

Accepted 3 April 2013

\section{Keywords:}

Brain-derived neurotrophic factor (BDNF)

Synaptic plasticity

Long-term potentiation (LTP)

Translation

RNA transport

\begin{abstract}
A B S T R A C T
Brain-derived neurotrophic factor (BDNF) is an important regulator of synaptic transmission and longterm potentiation (LTP) in the hippocampus and in other brain regions, playing a role in the formation of certain forms of memory. The effects of BDNF in LTP are mediated by TrkB (tropomyosin-related kinase B) receptors, which are known to be coupled to the activation of the Ras/ERK, phosphatidylinositol 3-kinase/Akt and phospholipase C- $\gamma$ (PLC- $\gamma$ ) pathways. The role of BDNF in LTP is best studied in the hippocampus, where the neurotrophin acts at pre- and post-synaptic levels. Recent studies have shown that BDNF regulates the transport of mRNAs along dendrites and their translation at the synapse, by modulating the initiation and elongation phases of protein synthesis, and by acting on specific miRNAs. Furthermore, the effect of BDNF on transcription regulation may further contribute to long-term changes in the synaptic proteome. In this review we discuss the recent progress in understanding the mechanisms contributing to the short- and long-term regulation of the synaptic proteome by BDNF, and the role in synaptic plasticity, which is likely to influence learning and memory formation.

This article is part of the Special Issue entitled 'BDNF Regulation of Synaptic Structure, Function, and Plasticity'.
\end{abstract}

(c) 2013 Elsevier Ltd. All rights reserved.

\section{Introduction}

In the mammalian nervous system, experience-dependent changes in synapse structure and function is thought to underlie learning and memory formation (Kandel, 2001). The long-term potentiation (LTP) of hippocampal synapses, particularly in the CA1 region, is the most studied form of plasticity, comprising three sequential steps: the short-term potentiation and the early-LTP (E-
LTP), which are transcription and translation independent and last for about 1-2 h, and the late LTP (L-LTP), which may last for hours to days and depend on transcription and translation activity (CostaMattioli et al., 2009; Malenka and Bear, 2004; Mayford et al., 2012).

The neurotrophin brain-derived neurotrophic factor (BDNF) has been shown to play a key role as mediator of activity-induced LTP in the hippocampus as well as in other brain regions (Bramham and Messaoudi, 2005; Cowansage et al., 2010; Lu et al., 2008;

Abbreviations: ADF, actin-depolymerizing factor; A2RE, heterogeneous nuclear ribonucleoprotein (hnRNP) A2 response element; Arc, activity-regulated cytoskeleton-

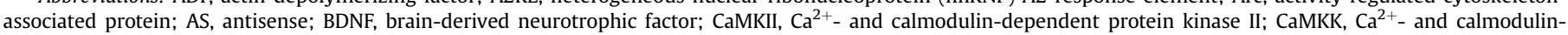

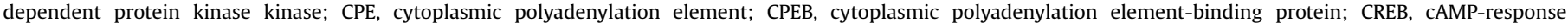

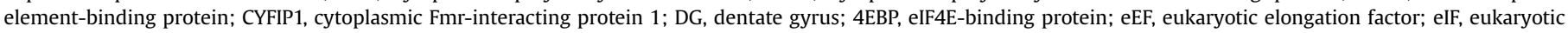

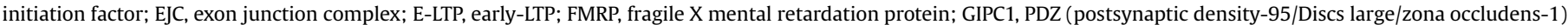

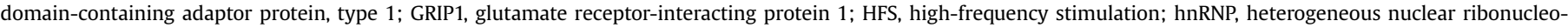

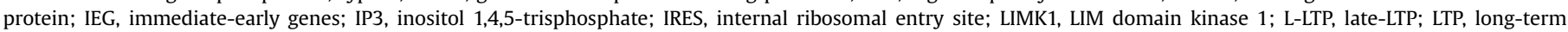

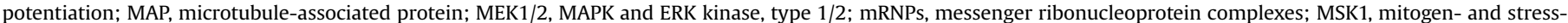

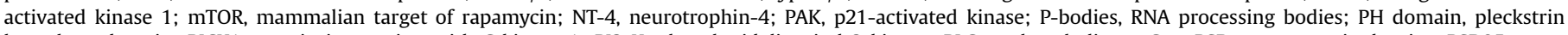

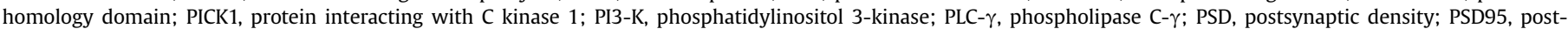

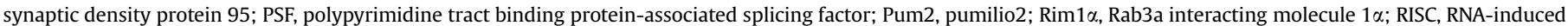

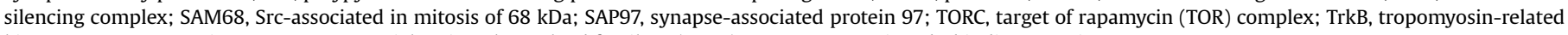
kinase B; TRPC3, transient receptor-potential cation channel subfamily C (TRPC), type 3; ZBP1, zipcode-binding protein 1.

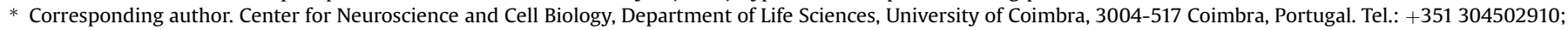
fax: +351239822776 .

E-mail address: cbduarte@ci.uc.pt (C.B. Duarte).

1 These authors contributed equally to this work. 
Minichiello, 2009; Park and Poo, 2013; Santos et al., 2010). The early effects of BDNF result from the modification of components already available at the synapse (e.g. protein phosphorylation) while the long-term effects arise from modification of translation activity at the synapse and changes in transcription. This has been investigated to a great extent in the hippocampus, and is the main focus of this review. The contribution of BDNF to the behavioral plasticity has been reviewed elsewhere (Cowansage et al., 2010) and will not be further discussed here.

\section{Dendritic transcripts}

The hypothesis of local protein synthesis at neuronal sites distant from the soma was raised after the work of Steward and Levy, who showed that polyribosomes can accumulate at the base of the dendritic spines forming a rosette-like structure (Steward and Levy, 1982), suggesting that they were bound to mRNA and involved in protein synthesis. This observation lead to the search for the mRNAs present in dendrites, and to the study of the mechanisms involved in their transport and how local protein synthesis is regulated at the synapse.

In highly polarized cells such as neurons, the transport of mRNAs coupled with local translation provides an important mechanism for spatial and temporal control of protein synthesis. Dendritic localized mRNAs are usually packaged into large messenger ribonucleoprotein complexes (mRNPs) that engage with motor proteins for the microtubule-dependent transport along dendrites. These transcripts are generally kept in a dormant state during the transport and then translated upon stimulation at or near activated synapses (Bramham and Wells, 2007) (Fig. 1). Several mRNAs were found to localize in dendritic processes under different physiological conditions. One of the major challenges of identifying dendritic mRNAs is the concentration of mRNAs in dendrites which is several times lower when compared with cell body-localized mRNAs, making somatic contamination a real issue.

The dendritic transcriptome is not yet fully characterized. The first estimations predicted that approximately 400 dendritic mRNAs could be present in the dendrites of cultured rat hippocampal neurons (Eberwine et al., 2001). A similar number of transcripts was identified in two other studies: i) in neurites of hippocampal neurons, using microarray analysis and a culture system that allows mechanical separation of axons and dendrites (129 mRNAs) (Poon et al., 2006); ii) in the stratum radiatum (dendritic lamina) from the rat hippocampal CA1 region (156 mRNAs) (Zhong et al., 2006). A different approach used consisted in the identification of conserved sequence elements in the transcripts that may explain their cellular localization and intracellular transport specificity (Lein et al., 2007). This strategy also predicted a low number of dendritic mRNAs (59 transcripts). A much higher number of transcripts was recently identified using deep RNA sequencing in microdissected synaptic neuropil (stratum radiatum and lacunosum moleculare) segments from the CA1 region of the
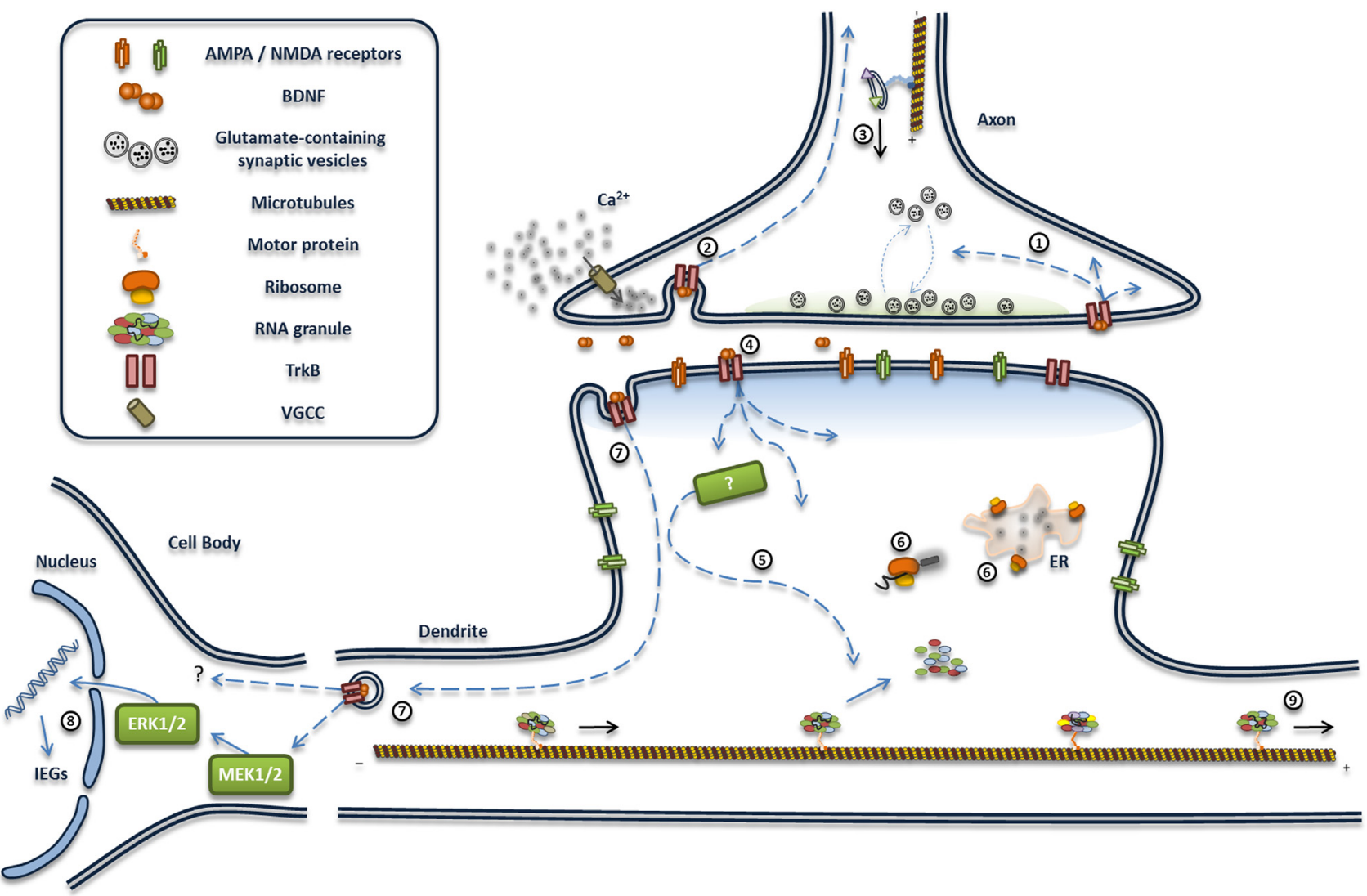

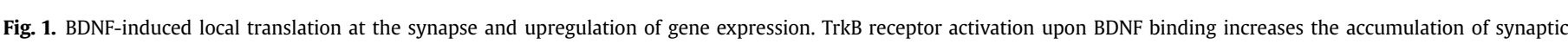

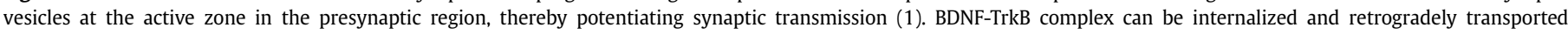

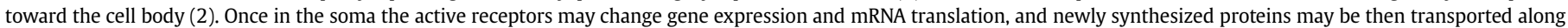

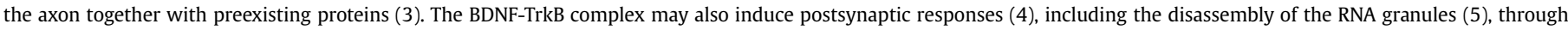

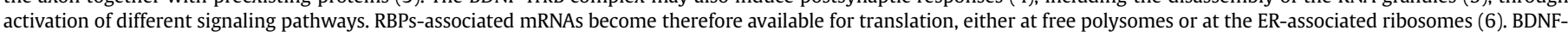

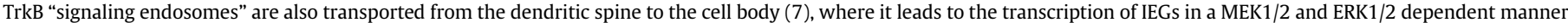

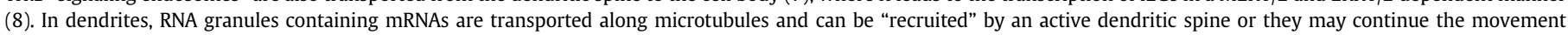
toward more distal sites (9). 
adult rat hippocampus (Cajigas et al., 2012). Since the neuropil tissue is comprised of dendrites, axons, glial cells, interneurons and blood vessels, the data obtained for the full neuropil transcriptome was filtered and 2550 mRNAs were attributed to dendrites and/or axons (Cajigas et al., 2012).

Comparison of the axodendritic transcriptome in hippocampal neurons with the whole rat genome clearly shows that certain functional categories are preferentially targeted to the neurite compartment. Fig. 2 shows such comparison for the "cellular component" category, using Gene Ontology enrichment analysis and visualization tool (GOrilla) (Eden et al., 2009). The analysis shows enrichment in mRNAs coding for proteins belonging to the ribonucleoprotein complex (ribosomal proteins and RNAbinding proteins) and synaptic proteins, including PSD components (Supplementary Fig. 1 and Supplementary Table 1 show a more detailed analysis). The "molecular function" group shows an enrichment in mRNAs which are translated into proteins with three main functions: (i) voltage gated ion channel activity, (ii) ubiquitinrelated activity and (iii) RNA binding activity (Supplementary Fig. 2). The analysis of axodendritic transcripts according to the "biological process" in which they participate show an enrichment in the following classes: (i) synaptic transmission, (ii) synaptic plasticity, (iii) learning and memory, (iv) RNA processing, (v) UPS-related processes and (vi) intracellular transport (Supplementary Fig. 3).

\section{BDNF and regulation of mRNA transport along dendrites}

\subsection{Cis-acting elements and mRNA transport into dendrites}

The evidence discussed in the previous section demonstrate that dendritic mRNA targeting is not a feature of a small subset of mRNAs as initially thought and confirms the enormous potential of localized translation in synaptic regulation. Among the dendritic mRNAs identified there are several transcripts encoding proteins with synaptic roles such as ionotropic and metabotropic receptors, scaffolding proteins, adhesion molecules, signaling molecules, and components of the translational machinery (Cajigas et al., 2012).
The use of high-resolution RNA in situ hybridization revealed the mRNA for CaMKII $\alpha\left(\mathrm{Ca}^{2+}\right.$ - and calmodulin-dependent protein kinase II, $\alpha$ subunit) as the most abundant in the neuropil region. The dendritic trafficking of this transcript and the role of local translated CaMKII $\alpha$ in synaptic plasticity events has been widely studied (Mayford et al., 1996; Miller et al., 2002; Ouyang et al., 1999). Other relatively abundant mRNAs in the neuropil region included the transcripts encoding for Shank1, PSD95 (postsynaptic density protein 95), Dendrin and MAP (microtubule-associated protein) $1 \mathrm{~A}$ (Cajigas et al., 2012), all of them previously reported as dendritic mRNAs (Bockers et al., 2004; Herb et al., 1997; Muddashetty et al., 2007; Tucker et al., 1989).

The selectivity of dendritic mRNA transport results from a complex and orchestrated series of events and is determined by the presence of cis-acting RNA elements which are recognized by trans-acting RNA-binding proteins. These ribonucleoprotein complexes may combine with other factors to form a functional complex which is transported along the microtubule cytoskeleton to its final destination (Doyle and Kiebler, 2011; Martin and Ephrussi, 2009). The cis-acting elements on the mRNAs (also called zipcodes or localization elements) can vary in length and in spatial arrangement and, with few exceptions, are contained in the 3 '-untranslated region (UTR) (Andreassi and Riccio, 2009). Nevertheless, the presence of localization elements in the $5^{\prime} \mathrm{UTR}$ and in the coding sequence has also been reported (Chiaruttini et al., 2009; Pal et al., 2003). One of the shortest, well described, zipcodes was found in MBP mRNA and is only 11-nucleotides long (Munro et al., 1999). This element is called heterogeneous nuclear ribonucleoprotein (hnRNP) A2 response element (A2RE) because it is recognized by hnRNPA2, a trans-acting factor responsible for MBP mRNA trafficking in oligodendrocytes (Munro et al., 1999). The A2RE-dependent targeting of mRNAs is also involved in the dendritic delivery of Arc, CaMKII $\alpha$, and Neurogranin mRNAs, which appear to cluster in the same hnRNPA2-containing granules (Gao et al., 2008). Moreover, hnRNPA2 was also shown to be necessary for the delivery of the non-coding BC1 RNA and PKM $\zeta$ mRNA to distal dendritic domains (Muslimov et al., 2006, 2011).

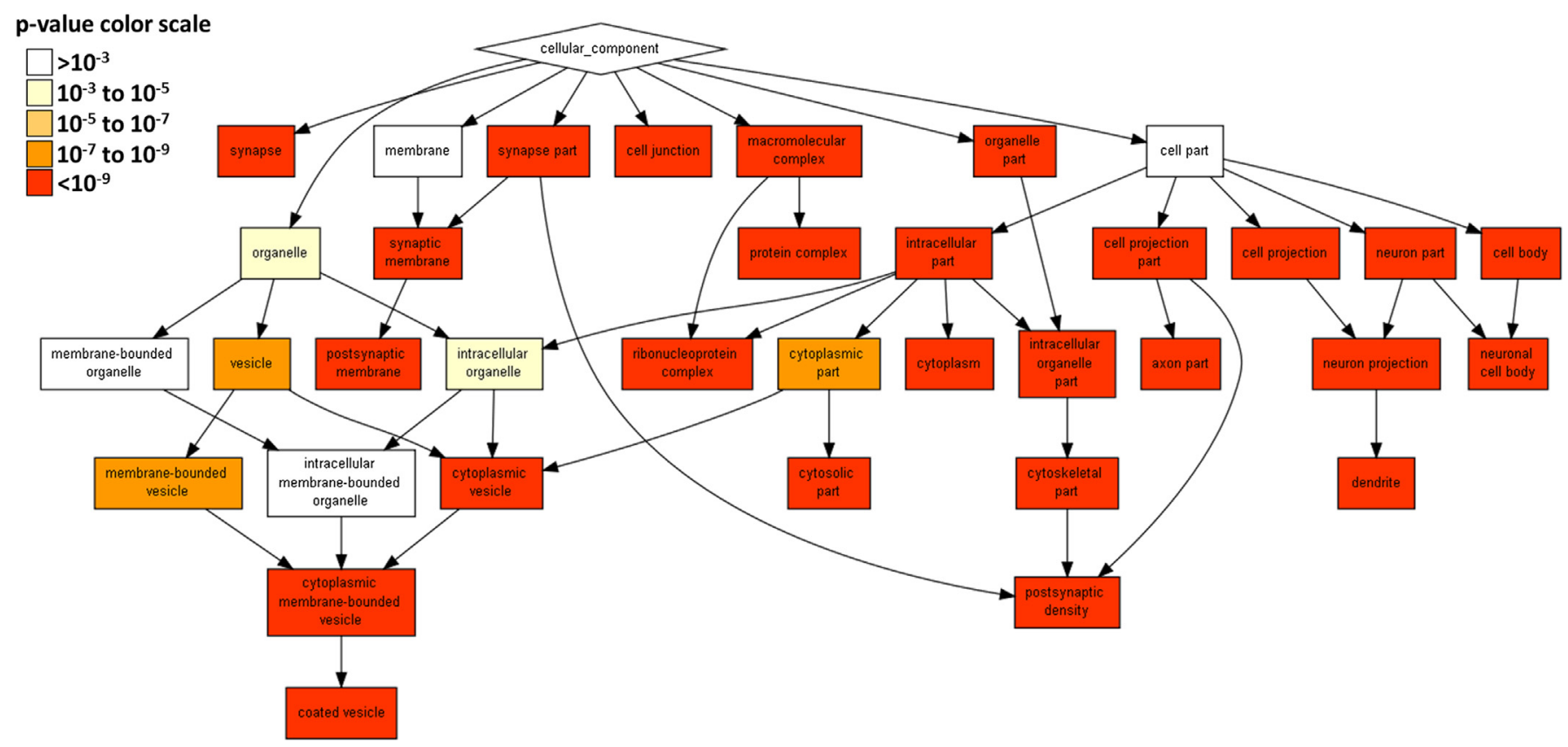

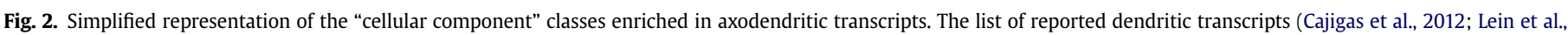

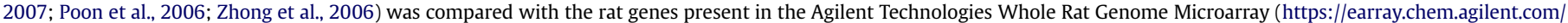

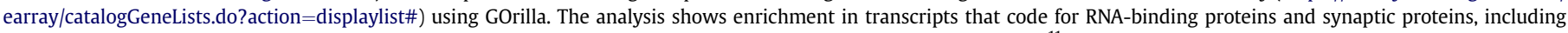
PSD components. The results focus on the classes of transcripts for which GO terms present a $p$-value lower than $10^{-11}$. 
Surprisingly, the interaction of the latter RNAs with hnRNPA2 depends on a non-canonical purine*purine interaction within BC1 and PKM $\zeta$ zipcodes, suggesting the existence of a spatial code mediating the targeting of these transcripts to dendrites by hnRNPA2 (Muslimov et al., 2011). In a recent study, the guanine $(G)$-quadruplex structures present in the 3'UTRs of CaMKII $\alpha$ and PSD95 mRNAs were shown to direct these transcripts into dendrites (Subramanian et al., 2011). Taken together, these results demonstrate that the RNA structure adopted by the zipcodes may be essential for the localization of the transcripts in the cell. Interestingly, several other well established dendritic mRNAs possess G-quadruplex structures in their $3^{\prime}$ UTR (Subramanian et al., 2011), which may indicate the presence of a common signature for the recognition of the cis-acting elements by the proper RNA-binding proteins. In fact, given the number of localized mRNAs, it is plausible to think that several localization elements could share structural characteristics that allow the recruitment of the appropriate transport apparatus.

The identification of localization elements within dendritic mRNAs can sometimes generate conflicting results. An early study identified a 94-nucleotide element in the 3'UTR of CaMKII $\alpha$ mRNA that was sufficient for the delivery of the transcript into dendrites (Mori et al., 2000). However, additional studies showed that CaMKII $\alpha$ mRNA containing this element but lacking most of the $3^{\prime}$ UTR fail to be targeted to dendrites in vivo (Miller et al., 2002). Furthermore, another localization element was identified in the middle of the 3'UTR of CaMKII $\alpha$ transcript (Blichenberg et al., 2001), and the CaMKII $\alpha$ transcript also contains a hnRNPA2 response element (A2RE) (Gao et al., 2008). Taken together, these findings suggest that the dendritic localization of CaMKII $\alpha$ mRNA depends on diverse cis-acting elements. Similarly, two different localization elements were described for the Arc mRNA (Gao et al., 2008; Kobayashi et al., 2005) but surprisingly little is known about the mechanism of Arc mRNA transport into dendrites. In hippocampal neurons the Arc transcripts are transported along dendrites in hnRNPA2-containing granules (Gao et al., 2008) and a cis-acting element on the $3^{\prime}$ UTR of the Arc mRNA showed a moderate ability to target these transcripts to dendrites (Kobayashi et al., 2005). However, it is currently unknown whether hnRNPA2 is required for Arc mRNA trafficking along dendrites in vivo and the identity of the trans-acting factors that recognize the localization element present in the Arc transcripts described by Kobayashi and coworkers also remains to be determined.

Another well described dendritic mRNA is the $\beta$-actin transcript. $\beta$-actin mRNA contains a cis-acting element 54-nucleotide long in the $3^{\prime} \mathrm{UTR}$, which is recognized by ZBP1 (zipcode-binding protein 1) and is essential for the localization of the transcript in the cytoplasm of cultured chick embryo fibroblasts (Kislauskis et al., 1994; Ross et al., 1997) and in neurites and growth cones of cultured chick forebrain neurons (Zhang et al., 2001). The complex ZBP1- $\beta$-actin mRNA accumulates in dendritic spines upon synaptic activity (Tiruchinapalli et al., 2003). In developing neurons the localization of ZBP1- $\beta$-actin mRNA in growth cones, which is coupled to localized $\beta$-actin translation, critically regulates growth cone navigation by mediating responses to external cues (Lin and Holt, 2007). In addition to the role in the localization of $\beta$-actin mRNA, ZBP1 also represses its translation (Huttelmaier et al., 2005). This is abrogated through Src-dependent phosphorylation of ZBP1, which results in the release of $\beta$-actin mRNA from ZBP1-containing granules and local translation of $\beta$-actin (Huttelmaier et al., 2005). Recent studies implicated the RNAbinding protein Src-associated in mitosis of $68 \mathrm{kDa}$ (Sam68) in the metabolism of $\beta$-actin mRNA in dendrites (Klein et al., 2013). The authors showed that knockdown of Sam68 or blocking the interaction of Sam68 with $\beta$-actin mRNA decreases the levels of $\beta$ - actin transcript in dendrites and results in fewer dendritic spines (Klein et al., 2013). In addition, absence of Sam68 results in a decreased number of functional synapses in vivo and reduces the amount of $\beta$-actin mRNA in synaptic polysomal fractions (Klein et al., 2013), suggesting that Sam68 may also be involved in the translational control of $\beta$-actin locally at the synapse.

A role for BDNF in the regulation of mRNA localization in dendrites has been suggested by several studies. Intrahippocampal infusion of BDNF resulted in the accumulation of Arc transcripts in dendrites and triggered long-term potentiation (BDNF-LTP) at medial perforant path-granule cell synapses in vivo (Messaoudi et al., 2007; Ying et al., 2002), and similar effects were observed in cultured cerebrocortical neurons (Rao et al., 2006), but the mechanisms involved have not been clarified. BDNF signaling induces the phosphorylation of ZBP1 and local synthesis of $\beta$-actin in growth cones, contributing to growth cone turning (Sasaki et al., 2010). In a recent study, ZBP1 was shown to regulate dendritic branching (Perycz et al., 2011). Interestingly, knockdown of ZBP1 inhibited the growth of dendritic protrusions in response to BDNF stimulation (Eom et al., 2003), suggesting that under limiting amounts of ZBP1 and $\beta$-actin mRNA in dendrites, neurons are not able to induce robust actin growth following stimulation with BDNF. Future studies should address the mechanisms underlying ZBP1-mediated transport of $\beta$-actin mRNA into dendrites, and possibly other mRNAs, and explore the molecular mechanisms by which BDNF regulates $\beta$-actin mRNA locally.

The effect of BDNF on the abundance of dendritic mRNAs was further investigated using a culture system that allows the mechanical separation of neurites from cell bodies (Manadas et al., 2009; Poon et al., 2006). BDNF differentially regulated the dendritic localization of transcripts encoding for several translationrelated proteins, including initiation and elongation factors, and aminoacyl-tRNA synthases (Manadas et al., 2009). However, it is not clear if BDNF regulates the delivery of these transcripts to dendrites and/or alters their stability.

\subsection{Dendritic targeting of BDNF $m R N A$}

The nuclear events, such as splicing and alternative polyadenylation site selection, may be essential determinants for the differential localization of mRNA in the cytoplasm (Giorgi and Moore, 2007). Perhaps the best example in mammalian neurons is the targeting of BDNF mRNA into dendrites. The presence of two polyadenylation sites in the BDNF transcript results in two distinct pools of mRNAs in the brain containing either a short or a long 3'UTR (Timmusk et al., 1993). The short 3'UTR-carrying mRNAs apparently are restricted to the soma whereas the long 3'UTRcontaining mRNAs are also found in dendrites (An et al., 2008). Nevertheless, BDNF constructs carrying a short 3'UTR were shown to be targeted to dendrites in cultured hippocampal neurons (Baj et al., 2011; Chiaruttini et al., 2009; Oe and Yoneda, 2010). The short 3'UTR-mediated dendritic targeting of the transcript may rely on the presence of cytoplasmic polyadenylation element (CPE)like motifs in its sequence (Oe and Yoneda, 2010). The CPE-like elements are apparently required for both constitutive and activity-dependent localization of the transcript in dendrites (Oe and Yoneda, 2010). In separated studies, the destination of BDNF mRNA was, ultimately, ruled by the presence of 5'UTR exons (Baj et al., 2011; Chiaruttini et al., 2009). The selective localization of several 5'UTR splice variants in dendrites was coupled to local TrkB activation and differentially modulates dendritic complexity (Baj et al., 2011). Importantly, blocking the dendritic localization of BDNF mRNA in vivo reduced BDNF protein levels in dendrites and resulted in deficits in dendritic spine pruning and enlargement (An et al., 2008). Deficits in dendritic synthesis of BDNF also lead to the 
selective impairment of LTP in dendrites (An et al., 2008). Together, these results suggest a critical role for dendritically synthesized BDNF in synaptic plasticity.

BDNF multiple transcripts can also be generated by alternative splicing of the $5^{\prime} \mathrm{UTR}$ region. As many as 11 different splicevariants of BDNF mRNA were described in both humans and rodents (Aid et al., 2007). Some of these variants show a differential distribution in hippocampal laminae in response to different incoming stimuli (Chiaruttini et al., 2008). It is not clear though, how the different forms of BDNF mRNA are sorted into distinct subcellular compartments. This process most likely requires additional and at the moment unknown factors. Translin binds to the coding sequence of BDNF mRNA regulating both constitutive and activity-induced transport of the transcript to dendrites (Chiaruttini et al., 2009). It was further demonstrated that, depending on the stimuli, translin may be required or not for BDNF mRNA trafficking (Wu et al., 2011). Interestingly, exogenous application of BDNF is sufficient to induce the transport of BDNF and TrkB mRNAs into dendrites in hippocampal neurons through the activation of the phosphatidylinositol 3-kinase (PI3-K) pathway (Righi et al., 2000).

\subsection{Nuclear history of dendritic-localized mRNPs}

Several RNA binding proteins that compose the dendritic mRNP complexes are nucleo-shuttling proteins highly expressed in the nucleus (Giorgi and Moore, 2007). These observations per se suggest that some trans-acting factors accompany the mRNA from transcription sites and ultimately regulate their localization in dendrites (Giorgi and Moore, 2007). One of the best examples of nuclear-acquired RNA binding proteins implicated in transcript localization comes from the exon junction complex (EJC), a set of proteins involved in mRNA splicing. Several proteins of the EJC, including Magoh, Y14, MLN14 and Barentsz, were detected in dendrites (Glanzer et al., 2005; Macchi et al., 2003). In particular the EJC protein eukaryotic initiation factor (eIF) 4AIII is present in neuronal RNA granules and binds several dendritic mRNAs such as the Arc transcript (Giorgi et al., 2007). However, EJC was not involved in the trafficking of Arc mRNA, but instead directed the transcript for degradation after translation (Giorgi et al., 2007).

Another example is related with the RNA-binding protein ZBP1. ZBP1 is mainly cytoplasmic, but its association with $\beta$-actin mRNA is likely to occur at transcription sites (Oleynikov and Singer, 2003; Pan et al., 2007). Interestingly, this interaction appears to be facilitated by ZBP2 (Pan et al., 2007). ZBP2 is predominantly nuclear but a small fraction of the protein colocalizes with cytoplasmic $\beta$-actin mRNA in both fibroblasts and neurons (Gu et al., 2002). Overexpression of a truncated form of ZBP2 disrupts the dendritic localization of $\beta$-actin transcripts (Gu et al., 2002). Altogether, these results suggest a cooperative role for ZBP1 and ZBP2 in the formation of functional nuclear mRNPs, and ultimately in the regulation of $\beta$-actin mRNA localization. Accordingly, the ZBP2-related protein MARTA1 binds with high affinity the dendritic targeting element in MAP2 mRNA (Rehbein et al., 2002) and it is suggested to have a role in both nuclear-export and dendritic trafficking of MAP2 mRNAs. The importance of nuclear-acquired factors in dendritic mRNA localization is also shown by the role played by the nuclear CAP-binding complex. The mRNA degradation factor LSm1 was shown to form dendritic-localized mRNPs that also contain the nuclear CAP-binding protein CBP80, which associates with mRNA percursors in the nucleus (di Penta et al., 2009). These results demonstrate that the LSm1-containing mRNPs are assembled in the nucleus.

The role of the nuclear compartment in the delivery of RNAs to dendrites was also addressed in experiments in which labeled RNAs were microinjected in the cytoplasm of hippocampal neurons. The transcripts were found along dendrites, showing that the delivery to this compartment does not require any nuclear event (Tubing et al., 2010). In most cases though, it is not clear how the nuclear history of endogenous dendritically targeted mRNAs regulates their localization.

\subsection{Trans-acting factors}

Among the best studied trans-acting factors that contribute to dendritic mRNA localization in neurons are the RNA-binding proteins ZBP1, Staufen, Fragile X mental retardation protein (FMRP), hnRNPA2, and the cytoplasmic polyadenylation element-binding protein (CPEB). The ultimate function of the trans-acting factors is to recognize cis-acting elements in the mRNAs and target the transcripts to distal dendrites. However, some of these RNAbinding proteins can also act as translation repressors (Huttelmaier et al., 2005; Jung et al., 2006; Napoli et al., 2008; Richter, 2007), linkers to motor proteins (Dictenberg et al., 2008; Falley et al., 2009) or even regulators of mRNA decay (Kim et al., 2005).

Staufen proteins are among the best characterized proteins regulating mRNA localization in many species. In mammals, Staufen is involved in the binding and targeting of mRNAs into dendrites (Kiebler et al., 1999; Tang et al., 2001). The Staufen family of proteins comprises two members, Staufen 1 and Staufen2, which are components of different RNA granules in neurons (Duchaine et al., 2002). Staufen2 is mainly expressed in the brain and is necessary for the microtubule-dependent delivery of CaMKII $\alpha$ mRNA to dendrites (Jeong et al., 2007). Staufen 1 is required for the late phase of long-term potentiation (L-LTP) in the hippocampus (Lebeau et al., 2008) whereas Staufen2 regulates mGluR-dependent long-term depression (mGluR-LTD) (Lebeau et al., 2011), suggesting distinct roles for the two Staufen proteins at the synapse.

Another important regulator of mRNA localization in neurons is FMRP. FMRP associates with several well described dendritic mRNAs, such as CaMKII $\alpha$, Arc, MAP1b, PSD95, as well as its own mRNA (Bassell and Warren, 2008). FMRP interacts directly with the motor protein kinesin to promote the transport of FMRP and cognate mRNAs along dendrites, further suggesting a role in the transport of ribonucleoprotein complexes along dendrites (Dictenberg et al., 2008). This study, together with the purification of KIF5-associated granules (Kanai et al., 2004), provided the best evidence for motor-based transport of RNA granules along the microtubule cytoskeleton. Another evidence for an interaction of trans-acting proteins and motor-based transport systems came from studies showing that the dendritic transport of Shank1 mRNA requires KIF5C and KIF5-associated protein Staufen1 (Falley et al., 2009). FMRP is also one of the best described factors that regulate the translation of mRNAs at the synapse. For instance, FMRP can recruit 4E-BP-like cytoplasmic Fmr-interacting protein 1 (CYFIP1) to repress the translation of target mRNAs (Napoli et al., 2008). Recent evidence indicate that FMRP can also repress the translation of cognate mRNAs through the association with miRNAs (Edbauer et al., 2010; Muddashetty et al., 2011) and through the reversible stalling of the ribosomes on polyribosomes containing FMRP-target mRNAs (Darnell et al., 2011).

RNG105 is an RNA-binding protein present in discrete RNA granules in dendrites of hippocampal neurons where it colocalizes with Staufen and CaMKII $\alpha$ mRNA (Shiina et al., 2005). BDNF induces the release of RNG105 from RNA granules which is coincident with the translation of an mRNA reporter near the granules (Shiina et al., 2005). However, the translation of RNG105associated mRNAs was still suppressed in the absence of RNG105 
(Shiina et al., 2010), suggesting that translation repression is not the primary role of RNG105. In fact, the RNG105 deficient mice showed reduced levels of RNG105-associated mRNAs in dendrites indicating a role for RNG105 in the dendritic localization of these mRNAs.

Another trans-acting factor required for dendritic mRNA transport is the CPEB. CPEB and the cytoplasmic polyadenylation complex are well known regulators of translation [(For a review see (Richter, 2007))] but less is known about the role of CPEB in mRNA trafficking. CPEB was shown to facilitate the transport of CPE (cytoplasmic polyadenylation element)-binding mRNAs to distal dendrites (Huang et al., 2003). It was recently shown that CPEBassociated proteins bidirectionally regulate the translation of specific mRNAs in dendrites resulting in a bidirectional regulation of LTP at hippocampal synapses (Udagawa et al., 2012), but whether CPEB is involved in the dendritic localization of those transcripts remains to be investigated.

\subsection{Molecular composition of RNA granules}

In the recent years, a great effort has been made to characterize the molecular composition of the granules responsible for the transport of RNAs. Hirokawa and coworkers purified large RNA granules from the mouse brain which were associated with the tail of conventional kinesin KIF5 (Kanai et al., 2004). These granules contained CaMKII $\alpha$ and Arc mRNAs as well as 42 different proteins. Among the identified proteins there are several well established trans-acting factors involved in mRNA localization such as Staufen, FMRP and Pur- $\alpha$. This proteomic approach also led to the identification of new players in mRNA transport such as hnRNPU and Polypyrimidine tract binding protein-associated splicing factor (PSF) (Kanai et al., 2004). Interestingly, several members of the hnRNP family of proteins that were detected in this RNA granule preparation were found to accumulate at postsynaptic sites upon neuronal activation (Zhang et al., 2012), further supporting their role in local mRNA regulation.

In a separated study, subcellular fractionation was used to obtain fractions enriched in ribonucleoprotein complexes from developing rodent cortex (Elvira et al., 2006). The composition of these granules was to some extent different from the KIF5associated granules described by Hirokawa and coworkers (Kanai et al., 2004). First, these granules were enriched in $\beta$-actin and did not contain CaMKII $\alpha$ or Arc transcripts. Second, proteomic analysis of these fractions revealed several RNA-binding proteins that were not detected in the KIF5-associated granules (Elvira et al., 2006). Nevertheless, the two granule preparations had many common components, including several hnRNPs, Staufen2, and DEAD-box3 helicase. Interestingly, it was further demonstrated that BDNF treatment increased the number of motile DEAD-box3carrying granules in hippocampal neurons (Elvira et al., 2006). Taken together, these results suggest that RNA granules are heterogeneous complexes and that some of their components might constitute general machinery for mRNA transport whereas others can be added specifically according to the mRNA/mRNAs that are transported.

One of the most important questions remaining in the field is related to the nature and number of mRNAs present in each ribonucleoprotein granule. The mRNAs encoding for Arc, CaMKII $\alpha$, and Neurogranin coassemble in the same set of hnRNPA2containing granules in cultured hippocampal neurons (Gao et al., 2008). Studies using labeled RNAs microinjected into the cytoplasm of hippocampal neurons showed that MAP2 and CaMKII $\alpha$ transcripts were sorted into distinct RNA granules in dendrites (Tubing et al., 2010). It was further demonstrated that endogenous MAP2, CaMKII $\alpha$, and $\beta$-actin mRNAs localize in distinct ribonucleoprotein particles which, unexpectedly, contained very few mRNA molecules (Mikl et al., 2011). Accordingly, in situ hybridization experiments with single molecule sensitivity to study 8 different and well established dendritic mRNAs showed that different mRNAs had little or no tendency to cluster together in the same granules and most likely were transported singly into dendrites (Batish et al., 2012). These recent findings suggest a simpler model in which solitary mRNAs can recruit their specific set of proteins and travel to distal dendrites, which may provide finer regulation of distinct mRNAs at individual synapses. Nevertheless, multiplexed mRNA trafficking has been observed in mammalian neurons (Gao et al., 2008) as well as in other biological contexts (Martin and Ephrussi, 2009). Moreover, RNA granules were observed with the RNA staining dye SYTO14 which indicates the presence of high RNA content (Knowles et al., 1996; Tang et al., 2001). Further research is required to determine the molecular composition of single RNA granules and to unravel the mechanisms orchestrating the assembly and the transport of these complexes along dendrites.

\subsection{BDNF regulation of $P$-bodies}

The population of RNA-containing granules in neurons is heterogeneous. They can be classified in RNA transport granules, stress granules, and RNA processing bodies [(P-bodies) (for further reading see (Anderson and Kedersha, 2006; Kiebler and Bassell, 2006)]. P-bodies are distinct cytoplasmic RNA granules that contain the components of the $5^{\prime}-3^{\prime}$ mRNA decay, nonsensemediated decay pathway and RNA-induced silencing complex (RISC). It was recently shown that BDNF treatment increased the formation of dendritic and somatic P-bodies that contain untranslated RNA targeted for repression or degradation (Huang et al., 2012). Furthermore, BDNF was shown to induce the translocation of dendritic P-body-like structures toward the distal regions of dendrites in hypothalamic neurons (Cougot et al., 2008). These P-body-like structures often contained ZBP1 and FMRP, well described RNA-binding proteins involved in mRNA transport (Cougot et al., 2008). These findings, together with the emerging roles of miRNAs in the regulation of local mRNAs, suggest a close interplay between P-bodies and RNA transport granules. Stimulation of hippocampal neurons with BDNF induced the dissociation of P-bodies (Zeitelhofer et al., 2008) which may suggest a model in which BDNF may relief P-bodies-mediated repression or decay. On the other hand, a general increase in miRNA biogenesis and in the formation of P-bodies was observed upon BDNF induction of Dicer in hippocampal neurons (Huang et al., 2012). Despite the apparent conflicting results, both studies demonstrated that P-bodies are dynamic entities that respond to BDNF treatment.

\section{BDNF and LTP in the hippocampus}

Work performed with trkB- or Bdnf-deficient mice showed that an impairment of the BDNF-TrkB signaling leads to a significant downregulation of early and late phases of LTP in the Schaffer Collateral-CA1 hippocampal synapses (Korte et al., 1995, 1996, 1998; Minichiello et al., 1999), which was correlated with a reduction in the performance in certain learning tasks (Gruart et al., 2007; Linnarsson et al., 1997; Minichiello et al., 1999; Pozzo-Miller et al., 1999; Xu et al., 2000). Importantly, the effects on LTP observed in mice carrying a null mutation in the $B d n f$ gene were reverted upon restoring the expression of the Bdnf gene or following treatment with recombinant BDNF (Korte et al., 1996; Patterson et al., 1996), further suggesting a role for BDNF in longterm synaptic potentiation in the hippocampus. In agreement 
with these findings, LTP is significantly inhibited when highfrequency stimulation (HFS) is performed in the presence of the BDNF and NT4 (neurotrophin-4) scavenger TrkB-IgG or with antiTrkB antibodies (Chen et al., 1999; Figurov et al., 1996; Kang et al., 1997; Korte et al., 1998). The Val66Met polymorphism in the Bdnf gene which results in a defect in regulated release of BDNF and affects episodic memory (Egan et al., 2003) also leads to an impairment of LTP (Ninan et al., 2010), further indicating a role for BDNF in this form of plasticity in the hippocampus. However, at this point the timing and relative role of the pre- and post-synaptic region in the release of BDNF still remains to be elucidated. This has been reviewed elsewhere (Lu et al., 2008; Park and Poo, 2013) and will not be further discussed here.

Facilitatory effects of BDNF in the induction of LTP have also been reported under conditions of weak synaptic stimulation that would not normally induce synaptic potentiation in the hippocampal CA1 region (Kovalchuk et al., 2002). Bath application of BDNF also triggers a sustained enhancement of synaptic transmission in the CA1 region of the hippocampus by a mechanism dependent on protein synthesis (Ji et al., 2010; Kang and Schuman, 1996). Transcription and translation activities are also required for BDNF-induced long-term potentiation at medial perforant path-granule cell synapses in vivo following intrahippocampal infusion of the neurotrophin (Messaoudi et al., 2007; Ying et al., 2002).

The TrkB receptors for BDNF are expressed in axons, nerve terminals and dendritic spines of the hippocampal granule and pyramidal neurons of the adult rat hippocampus (Carvalho et al., 2008; Drake et al., 1999; Pereira et al., 2006) raising the question of whether the neurotrophin acts at the pre- and/or post-synaptic level in LTP, and the signaling mechanisms involved. The TrkB receptors are coupled to the activation of multiple signaling pathways, including the Ras/ERK pathway and the PI3-K/Akt pathway, initiated by interaction of Shc with the phosphorylated receptor, and the phospholipase C $-\gamma$ (PLC- $\gamma$ ) (Carvalho et al., 2008). Studies performed in mice with targeted mutations in either the Shc or the PLC $-\gamma$ binding sites of TrkB showed that the latter mechanism is preferentially coupled to potentiation of the CA3-CA1 synapse and associative learning (Gruart et al., 2007; Minichiello et al., 2002). Furthermore, inhibition of the PLC $-\gamma$ pathway at the pre- and or post-synaptic level, by overexpression of the PLC- $\gamma$ pleckstrin homology domain $(\mathrm{PH})$ with a viral vector, showed a role for pre- and post-synaptic TrkB receptors in LTP in the hippocampal CA1 region (Gartner et al., 2006). Interestingly, in this study concurrent inhibition of pre- and post-synaptic PLC- $\gamma$ signaling was required to reduce LTP to levels similar with those observed in trkB and $B d n f$ knockout mice, and no significant effects were detected in experiments testing the effect of pre- or post-synaptic inhibition of this pathway (Gartner et al., 2006). Recruitment of $\mathrm{Ca}^{2+}$ from inositol 1,4,5-trisphosphate (IP3)-sensitive intracellular stores was suggested to play a key role in LTP downstream of PLC- $\gamma$ activation (Gartner et al., 2006).

A different study addressed the relative role of pre- and postsynaptic TrkB receptors in LTP using mutant mice with reduced expression of the receptor throughout the brain, including the CA3 and CA1 regions, and mice lacking TrkB in the hippocampus CA1 region (Xu et al., 2000). LTP was affected only in the former animal model, similarly to the results obtained in the studies with preand/or post-synaptic inhibition of PLC $-\gamma$ signaling. However, in this study no experiments were performed to analyze the response in mice lacking presynaptic TrkB receptors and therefore the authors concluded that BDNF would target presynaptic TrkB receptors to induce synaptic potentiation. In contrast with the reports suggesting a concurrent role of pre- and post-synaptic TrkB receptors in LTP in the CA1 region of the hippocampus, a postsynaptic effect was proposed to account for the robust induction of LTP at the synapses of the medial perforant path fibers when BDNF was applied together with a weak synaptic stimulation that would not normally induce synaptic potentiation (Kovalchuk et al., 2002). Although a presynaptic effect of BDNF was not ruled out in this paradigm, the differences may be due to the distinct synapses investigated.

\subsection{Transcription- and translation-independent synaptic regulation by BDNF}

The role of BDNF in the early phase of LTP is likely dependent on the post-translational regulation of pre- and post-synaptic proteins (Figs. 1 and 3). At the presynaptic level the activation of TrkB receptors was shown to upregulate depolarization-evoked glutamate release from isolated hippocampal and cerebrocortical synaptosomes (Jovanovic et al., 2000; Pascual et al., 2001; Pereira et al., 2006; Simsek-Duran and Lonart, 2008). Studies performed in cultured hippocampal neurons showed that BDNF increases the frequency of miniature excitatory postsynaptic currents, further supporting a presynaptic effect of the neurotrophin (Lessmann and Heumann, 1998; Li et al., 1998; Schinder et al., 2000; Tyler and Pozzo-Miller, 2001). The rapidly recycling pool of synaptic vesicles is targeted by a BDNF-dependent mechanism in the hippocampal CA1 region, and this modulation was shown to be necessary for the enhancement of exocytosis caused by induction of LTP (Tyler et al., 2006). The recycling of synaptic vesicles induced by BDNF requires the presence myosin $\mathrm{VI}$, a minus end-directed actin-based motor, and the adaptor protein GIPC1 [PDZ (postsynaptic density95/Discs large/zona occludens-1) domain-containing adaptor protein, type 1], which form a complex that can engage TrkB receptors (Yano et al., 2006). However, how myosin VI contributes to the BDNF-induced regulation of the exocytotic release of glutamate remains to be elucidated.

The potentiation of glutamate release by BDNF was not observed is cerebrocortical synaptosomes isolated from synapsin I and synapsin II deficient mice (Jovanovic et al., 2000), an ERK substrate that interacts with small synaptic vesicles. These results suggest that TrkB receptor activation coupled to synapsin phosphorylation may dissociate the synaptic vesicles from actin filaments, thereby increasing vesicle docking and glutamate release. Accordingly, BDNF increased the number of docked vesicles per active zone at CA1 spine synapses in hippocampal slice cultures, but since in these experiments the treatment with the neurotrophin was performed for $48 \mathrm{~h}$, the effect may involve, at least in part, translation activity (Tartaglia et al., 2001).

Synaptic potentiation by BDNF is also dependent on the small GTP-binding protein Rab3a, which is known to play a role in vesicular trafficking. Rab3a is associated with synaptic vesicles and the BDNF-induced upregulation of neurotransmitter release was shown to be impaired in cultured hippocampal neurons form Rab3a knockout mice (Alder et al., 2005; Thakker-Varia et al., 2001). A role for Rab3a in the presynaptic effects of BDNF is further suggested by the results showing an impairment of the BDNF-induced potentiation of glutamate release in synaptosomes isolated from the CA1 region of Rim $1 \alpha$ (Rab3a interacting molecule $1 \alpha$ ) knockout mice (Simsek-Duran and Lonart, 2008). Rim1 $\alpha$ is a Rab3a effector molecule, being phosphorylated by an ERK-dependent mechanism following stimulation of CA1 nerve terminals with BDNF. However, the Rim $1 \alpha$ downstream targets in BDNF-induced potentiation of glutamate release remain to be identified.

Protein phosphorylation following activation of postsynaptic TrkB receptors may also contribute to the effects of BDNF on E-LTP (Fig. 3). This may be due to phosphorylation of plasma membraneassociated NMDA receptors, as shown for the GluN1 and GluN2B 


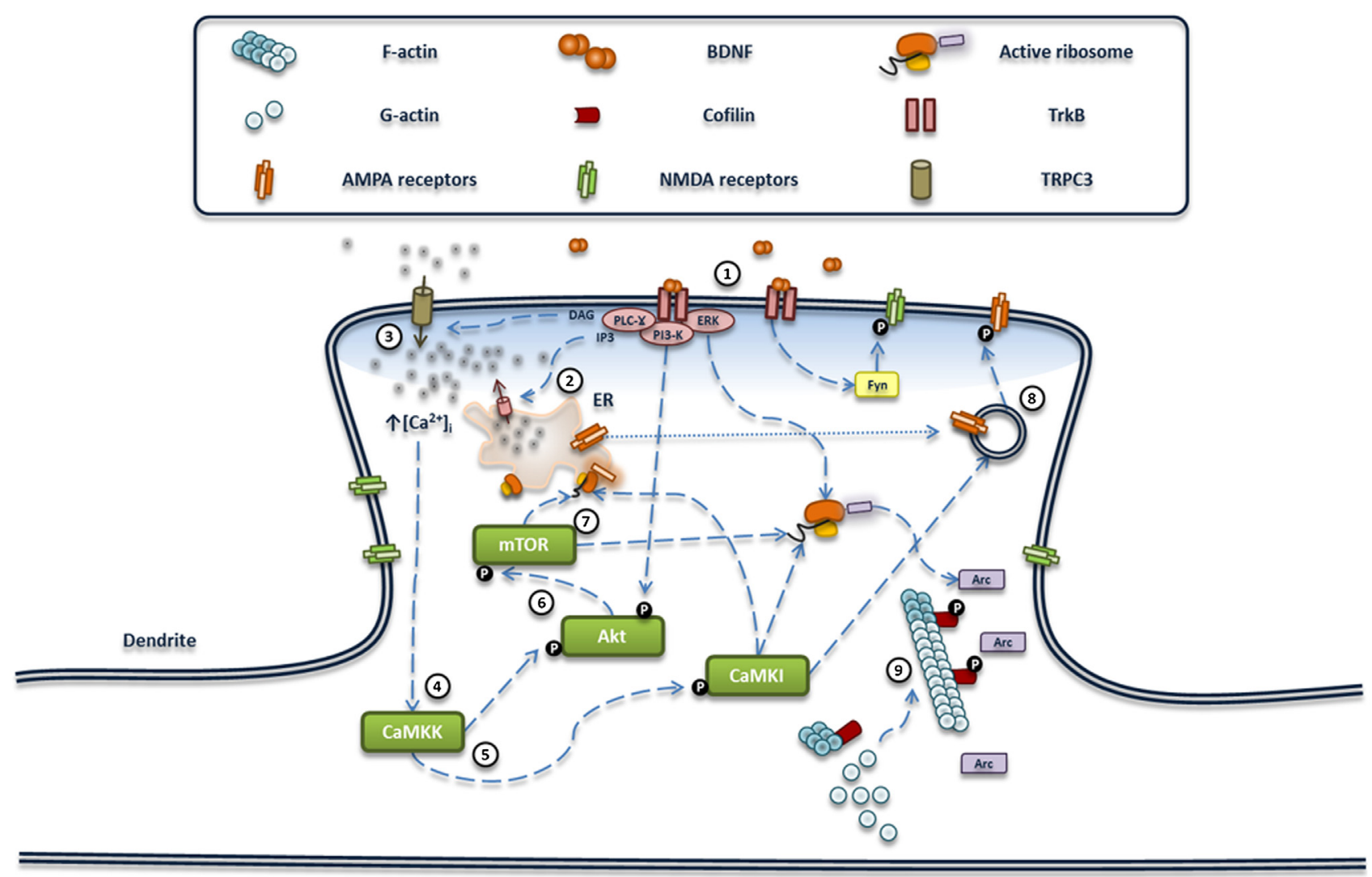

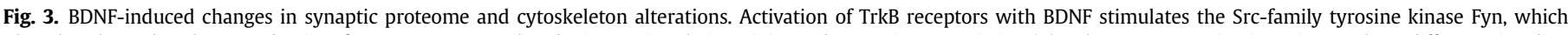

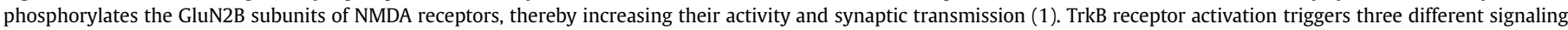

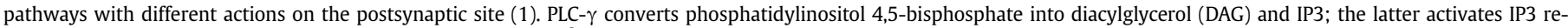

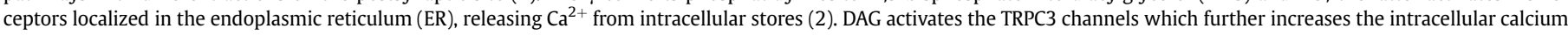

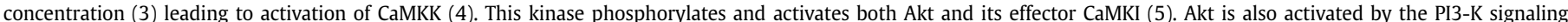

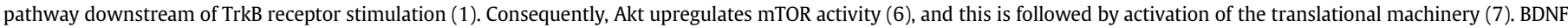

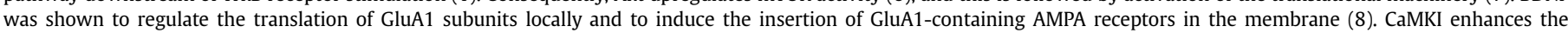

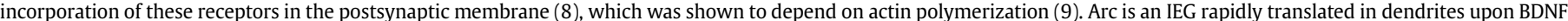
stimulation (7), being necessary to keep cofilin in the phosphorylated state and making possible F-actin elongation (9).

subunits (Lin et al., 1998; Suen et al., 1997), which may account for BDNF-induced increase in the receptor open probability observed in cultured hippocampal neurons (Levine et al., 1998). Accordingly, the effects of BDNF on the electrophysiological properties of NMDA receptors depend on GluN2B subunits (Levine and Kolb, 2000). BDNF was also shown to increase the phosphorylation of GluA1 AMPA receptor subunits in cultured organotypic hippocampal slices and increased synaptic delivery of AMPA receptors within about $30 \mathrm{~min}$ (Caldeira et al., 2007a), further contributing to an increased postsynaptic response to glutamate release. Similar effects of BDNF on the synaptic accumulation of GluA1 containing AMPA receptors were reported in cultured cortical (Nakata and Nakamura, 2007) and hippocampal neurons (Fortin et al., 2012).

The rapid pre- and post-synaptic events induced by BDNF, mediated by phosphorylation of existing proteins, are likely to be transient since the activity of protein phosphatases may revert the effects induced by TrkB receptor activation. These initial effects are followed by more sustained synaptic changes, which involve alterations in the synaptic protein content, and contribute to the L-LTP.

\subsection{BDNF and regulation of translation machinery}

In addition to the effects in the regulation of the assembly of RNA granules (see Section 3.6), BDNF promotes translation of specific mRNAs by regulating the activity of the protein synthesis machinery. Translation is initiated with the formation of the eIF4F complex, followed by recruitment of the ribosome and the mRNA molecule. The eIF4F is comprised by the eIF4E subunit, which binds the 5'-capped mRNAs, the eIF4A, responsible for unwinding the secondary structure of mRNAs, and the eIF4G, which bridges the transcript to the $43 \mathrm{~S}$ pre-initiation complex. The formation of this complex and induction of translation activity is promoted by phosphorylation of eIF4E-binding proteins (4EBPs) (Pestova et al., 2007), which prevents their interaction of eIF4e. The initiation steps of translation are followed by recruitment of elongation factors, including the eukaryotic elongation factor (eEF) 2, which promote the translocation of the new protein chain from the A-site to the P-site of the ribosome (Taylor et al., 2007).

The initiation and elongation steps of translation are considered rate-limiting, being subjected to regulation at multiple sites (Herbert and Proud, 2007; Santos et al., 2010). BDNF is thought to act at different levels to increase translation activity, by altering the phosphorylation of proteins involved in the initiation and elongation steps of protein synthesis. Stimulation of cultured cerebrocortical neurons with BDNF was shown to induce the phosphorylation of eIF4E and 4EBP1, by activating the ERK and PI3-K signaling pathways, respectively (Takei et al., 2004).

Furthermore, the BDNF-induced 4EBP1 phosphorylation was sensitive to mTOR inhibition with rapamycin (Takei et al., 2004). A BDNF-induced increase in the phosphorylation of 4EBP1, p70S6 
kinase and its substrate ribosomal S6 protein was also demonstrated in the dendrites of cultured cortical neurons and in synaptoneurosomes (subcellular fraction containing the pre- and postsynaptic regions) isolated from the brain cortex (Takei et al., 2004). The mTOR-dependent phosphorylation of 4EBP1 enhances capdependent translation, by inducing eIF4F complex formation, whereas the activation of the S6 kinase pathway enhances translation initiation of $5^{\prime}$-oligopyrimidine tract-containing mRNAs, such as those coding for ribosomal proteins and elongation factors (Fumagalli and Thomas, 2000). Therefore, the effects of BDNF on protein synthesis in dendrites are likely to be mediated by at least two translation initiation pathways.

An additional effect of BDNF on translation initiation is mediated by phosphorylation of the guanine nucleotide exchange factor eIF2B (Takei et al., 2001). This initiation factor catalyzes the exchange of eIF2.GDP to eIF2.GTP, which is required for the assembly of the eIF2.GTP.Met.tRNAi complex (Rhoads, 1999) and for priming each $40 \mathrm{~S}$ ribosomal subunit. Studies performed in cultured cortical neurons showed that BDNF increases the phosphorylation of glycogen synthase kinase-3 $\beta$, which is known to regulate the eIF2B activity, and this may constitute an additional mechanism to promote translation activity following activation of the TrkB receptors by BDNF (Takei et al., 2001).

Several pieces of evidence suggest that the effects of BDNF in synaptic potentiation may be mediated, at least in part, by promoting translation initiation. A BDNF-induced increase in the phosphorylation of eIF4E, which is correlated with enhanced rates of translation (Gingras et al., 2004), was also observed in dentate gyrus (DG) following infusion of BDNF to induce LTP (BDNF-LTP) and in DG synaptoneurosomes stimulated with BDNF (Kanhema et al., 2006). Furthermore, BDNF infusion into the DG of anesthetized animals was found to increase eIF4E total protein levels, further suggesting that eIF4E upregulation induces local protein synthesis at the synapse, and may contribute to the effects of BDNF in synaptic potentiation. A role for mTOR was also shown in the late phase-LTP at hippocampal CA1 synapses induced by presynaptic tetanic stimulation and in the BDNF-induced synaptic potentiation (Tang et al., 2002), two forms of plasticity that require protein synthesis. Based on studies with conditional expression of a dominant negative form of MEK1 in the postnatal murine forebrain it was suggested that the translation efficiency necessary for establishing long-term synaptic plasticity may involve the functional interplay between mTOR- and the ERK-dependent signaling pathways (Kelleher et al., 2004).

BDNF also regulates translation activity by acting at the elongation step. In cultured cortical neurons BDNF was shown to increase the phosphorylation (activation) of eukaryotic elongation factor $1 \mathrm{~A}$ (eEF1A), which is known to recruit aminoacyl-transfer RNA (tRNA) to the A-site of ribosomes when bound to GTP (Inamura et al., 2005). eEF2, a GTP-binding protein required for the second step of elongation (ribosomal translation), is also regulated by BDNF, although contrasting results were obtained in different preparations. Local infusion of BDNF was shown to induce a rapid and transient increase in eEF2 phosphorylation in the hippocampal dentate gyrus, under conditions that induce LTP (BDNF-LTP) (Kanhema et al., 2006). This alteration in eEF2 phosphorylation at Thr56 is typically associated with a reduction in the interaction of the elongation factor with ribosomes, thereby decreasing global protein synthesis (Nairn and Palfrey, 1987; Ryazanov et al., 1991, 1988), but an increase in the translation of some dendritic mRNAs (e.g. $\alpha$ CaMKII and Arc) has also been reported (Belelovsky et al., 2005; Chotiner et al., 2003; Marin et al., 1997; Park et al., 2008; Scheetz et al., 2000). However, in contrast with the results obtained following injection of BDNF in the dentate gyrus, the neurotrophin was without effect on eEF2 phosphorylation in synaptoneurosomes isolated from the same region, suggesting that the arresting of elongation may be limited to non-synaptic sites. At the synapse, BDNF induces the phosphorylation of eIF4E (see above), thereby increasing protein synthesis, whereas in non-synaptic regions translation activity may be $5^{\prime}$-cap-independent and mediated by IRES [internal ribosomal entry site (Costa-Mattioli et al., 2009)]. The regulation of eEF2 in neurons may be more complex and will require further investigation, since studies performed in cultured cerebrocortical neurons showed a decrease in the phosphorylation of this elongation factor following acute and chronic stimulation with BDNF, which favors the interaction with the ribosomes and protein synthesis (Inamura et al., 2005; Nairn and Palfrey, 1987; Ryazanov et al., 1988; Takei et al., 2009).

Interestingly, neuronal activity in hippocampal cultures was also shown to have differential effects on eEF2 phosphorylation in dendrites and in the soma (Verpelli et al., 2010). The activityinduced eEF2 phosphorylation in dendrites is mediated via activation of metabotropic glutamate receptors and correlates with protein synthesis (e.g. dendritic synthesis of BDNF). Furthermore, in this model the activity-induced synthesis of BDNF increases spine maturation and density (Verpelli et al., 2010), but direct in vivo evidence for local synthesis of BDNF in response to LTPinducing activity are still not available. Differential mechanisms of regulation of translation activity were also reported in Aplysia sensory neurons, where the target of rapamycin complex 1 (TORC1)-mediated phosphorylation of S6 kinase contributes to long-term facilitation of sensory-motor neuron synapses, which requires protein synthesis. In contrast, S6 kinase does not play a role in TORC1-mediated increase in somatic cap-dependent translation in cultured Aplysia sensory neurons (Weatherill et al., 2010).

\subsection{BDNF and spine plasticity}

Synaptic stimulation under conditions that induce LTP of excitatory synapses is also associated with sustained structural alterations in the postsynaptic region, including an increase in the number of dendritic spines and their volume (Kasai et al., 2010). BDNF may contribute to some of these alterations since the sustained enlargement of synaptic spines at the hippocampal CA3-CA1 synapses in response to LTP-inducing synaptic stimulation was shown to depend on endogenous BDNF and required protein synthesis (Tanaka et al., 2008). A role for BDNF in structural spine plasticity is further supported by studies with exogenous application of the neurotrophin to dissociated cultures of hippocampal neurons and hippocampal slice cultures (Alonso et al., 2004; Amaral and PozzoMiller, 2007; Ji et al., 2010; Tyler and Pozzo-Miller, 2003, 2001). BDNF stimulation increases synaptic spine density by a mechanism dependent on the Ras/ERK pathway (Alonso et al., 2004) and the transient receptor-potential cation channel subfamily C (TRPC) type 3 (Amaral and Pozzo-Miller, 2007). Studies performed in hippocampal slices from adult rats showed that BDNF mediates the thetaburst stimulation-induced increase in actin polymerization in dendritic spines, through regulation of p21-activated kinase (PAK) and ADF (actin-depolymerizing factor)/cofilin (Rex et al., 2007). An increase in actin polymerization in spines may also arise from activation of m-calpain through ERK-dependent phosphorylation, as shown in cultured neurons (Zadran et al., 2010). F-actin polymerization in spines plays a key role in LTP maintenance in vivo (Fukazawa et al., 2003) and, therefore, these alterations may underlie some of the effects of BDNF in long-term synaptic potentiation.

\subsection{BDNF-induced changes in the neuronal proteome}

The analysis of the neuronal proteome in a given brain region or in cell cultures is a useful approach to evaluate which are the 
proteins regulated by certain stimuli, but it does not provide information regarding the subcellular localization of the nascent proteins. A gel-based proteome profiling of the long-term (12 h) effects of BDNF in cultured hippocampal neurons identified 29 proteins that were upregulated and 17 proteins downregulated, for a total of 46 proteins altered by BDNF (Manadas et al., 2009). Bioinformatic analysis of the proteins using GOMiner showed an upregulation of proteins related to RNA metabolic processes and cellular protein metabolic processes, such as proteolysis (related to the ubiquitin-proteasome system) and translation (regulators of translation initiation and elongation) (Manadas et al., 2009). These results suggest that BDNF regulates the proteome by acting both on de novo protein synthesis and by affecting the rate of degradation of proteins targeted by the ubiquitin-proteasome system (Manadas et al., 2009), but provide no evidence regarding local translation at the synapse.

The first experimental evidence for a role of BDNF in the activation of local translation in dendrites of hippocampal were obtained using a reporter in which the coding sequence of GFP was flanked by the $5^{\prime}$ - and 3'-UTR regions from CaMKII $\alpha$, providing both dendritic mRNA localization and translational regulation (Aakalu et al., 2001). This was later supported by results showing effects of BDNF on the translation machinery in dendrites of cultures cerebrocortical neurons (Takei et al., 2004) as well as in synaptoneurosome preparations (Kanhema et al., 2006; Takei et al., 2004). The effect of BDNF on the synaptic proteome was analyzed in more detail in synaptoneurosomes isolated from cultured cortical neurons, using multidimensional protein identification technology (MudPIT) and relative quantification by spectra counting. Since synaptoneurosomes were isolated $30 \mathrm{~min}$ after stimulation of the neurons with BDNF it was suggested that the alterations observed were due to local protein synthesis at the synapse. This study showed 410 proteins regulated by BDNF in synaptoneurosomes, 214 of which were upregulated and 196 were found to be downregulated (Liao et al., 2007). Analysis of the synaptic proteins upregulated by BDNF with GOrilla (Eden et al., 2009) shows proteins related to translation processes, belonging to both ribosomes and ribonucleoprotein complexes (Fig. 4; see also Supplementary Figs. 4-6 and Supplementary Table 2). Different classes of proteins were found in the group downregulated following stimulation with BDNF, and included cytoskeletal-related proteins in both "molecular function" and "cellular component" categories, and also proteins associated with metabolic processes in the "biological process" group (Supplementary Figs. 7-9 and Supplementary Table 3). The fact that translation-related proteins are increased at the synapse following stimulation with BDNF may constitute a positive feedback mechanism to amplify the effect of the neurotrophin on translation activity, and further supports the pivotal role of BDNF in the regulation of both synaptic function and plasticity.

In addition to the proteins identified in the proteomics analysis discussed above, target oriented studies have shown effects of BDNF in total expression of AMPA and NMDA receptor subunits in cultured hippocampal and cortical neurons (Caldeira et al., 2007a, 2007b; Fortin et al., 2012; Guire et al., 2008; Narisawa-Saito et al., 1999; Small et al., 1998). Interestingly, stimulation of hippocampal neurons with BDNF also increased the synaptic accumulation of GluA1 AMPA receptor subunit, by a mechanism dependent on mTOR and $\mathrm{Ca}^{2+}$ - and calmodulin-dependent protein kinase kinase (CaMKK) (Caldeira et al., 2007a; Fortin et al., 2012; Guire et al., 2008). BDNF also upregulated GluA1 protein levels in rat forebrain synaptoneurosomes, further indicating that the neurotrophin induces local translation of AMPA receptors at the synapse (Schratt et al., 2004).

The anchoring and stabilization of glutamate receptors at the synapse is controlled by scaffold proteins which interact with other postsynaptic density (PSD) components, including signaling molecules. BDNF was also shown to upregulate the PSD scaffold protein Homer2 in rat forebrain synaptoneurosomes (Schratt et al., 2004), suggesting an effect of the neurotrophin in strengthening the postsynaptic machinery involved in the response to glutamate. Furthermore, BDNF increased the protein levels of the PSD scaffold proteins SAP97 (Synapse-associated protein 97), GRIP1 (glutamate receptor-interacting protein 1 ) and Pick1 (protein interacting with C kinase 1) in cultured cerebrocortical neurons (Jourdi et al., 2003), but it remains to be determined whether these proteins are also locally translated at the synapse. Since the mRNA for SAP97 was identified in the neurite compartment in the CA1 region of the hippocampus (Cajigas et al., 2012) this scaffold protein may be locally translated at the synapse in response to BDNF stimulation. BDNF also induces the translation of signaling proteins, as shown for CaMKII $\alpha$ (Takei et al., 2004). The $\mathrm{Ca}^{2+}$ - and calmodulindependent protein kinase II is a major constituent of the PSD and plays a structural role in enlarging and strengthening the synapse in the late phases of LTP (Lisman et al., 2012).

Arc is a postsynaptic protein encoded by a gene belonging to the class of immediate-early genes (IEGs), which are rapidly and transiently transcribed in response to synaptic activity (Link et al., 1995; Steward et al., 1998), playing an important role in synaptic plasticity in the hippocampus [reviewed in (Bramham et al., 2010)]. The dendritic localization and translation of the Arc mRNA has been extensively studied (Messaoudi et al., 2007; Rao et al., 2006; Steward et al., 1998; Steward and Worley, 2001; Yin et al., 2002; Ying et al., 2002), and BDNF was shown to increase dendritic Arc mRNA and protein levels in cultured cortical neurons (Rao et al., 2006). A role for Arc in LTP was shown in experiments with intrahippocampal infusion of antisense (AS) oligodeoxynucleotides to inhibit Arc protein expression, which impaired the maintenance phase of LTP without affecting its induction (Guzowski et al., 2000). Furthermore, a sustained local Arc synthesis in dendrites is necessary for the maintenance of LTP (Messaoudi et al., 2007). Interestingly, intrahippocampal infusion of BDNF also resulted in the accumulation of Arc transcript in dendrites and triggered longterm potentiation (BDNF-LTP) at medial perforant path-granule cell synapses in vivo by an Arc-dependent mechanism (Messaoudi et al., 2007; Ying et al., 2002). Despite the evidence indicating an effect of BDNF in the Arc translation, no Arc mRNA was described in the group of transcripts identified in the polysomal fraction following stimulation of cerebrocortical neurons with BDNF (Schratt et al., 2004). This apparent discrepancy may suggest that BDNF is preferentially coupled to the translation of the Arc mRNA at the synapse.

Although it is presently clear that Arc plays a role in LTP induced by HFS and in BDNF-LTP, the mechanism(s) involved are not fully elucidated. The upregulation of Arc may act in synaptic potentiation by promoting the phosphorylation and consequent inhibition of cofilin, an actin-binding protein which regulates actin polimerization. Accordingly, the induction of LTP in the hippocampal CA1 region (in brain slices) and in the dentate gyrus (in vivo) was shown to promote the phosphorylation of cofilin, thereby inhibiting its activity and increasing actin polimerization (Chen et al., 2007; Fukazawa et al., 2003). The infusion of Arc AS $2 \mathrm{~h}$ post-HFS was shown to decrease the amount of phospho-cofilin present in the dentate gyrus homogenate which correlates with the loss of nascent F-actin at medial perforant path synapses and blockade of LTP consolidation (Messaoudi et al., 2007). The same study showed that jasplakinolide, an F-actin-stabilizing drug, blocked the Arc AS effect on LTP (Messaoudi et al., 2007), further suggesting that Arc couples translation activation to F-actin expansion and LTP stabilization. These findings suggest that Arc-induced cytoskeleton remodeling is a key event in the formation of a stable L-LTP, which 


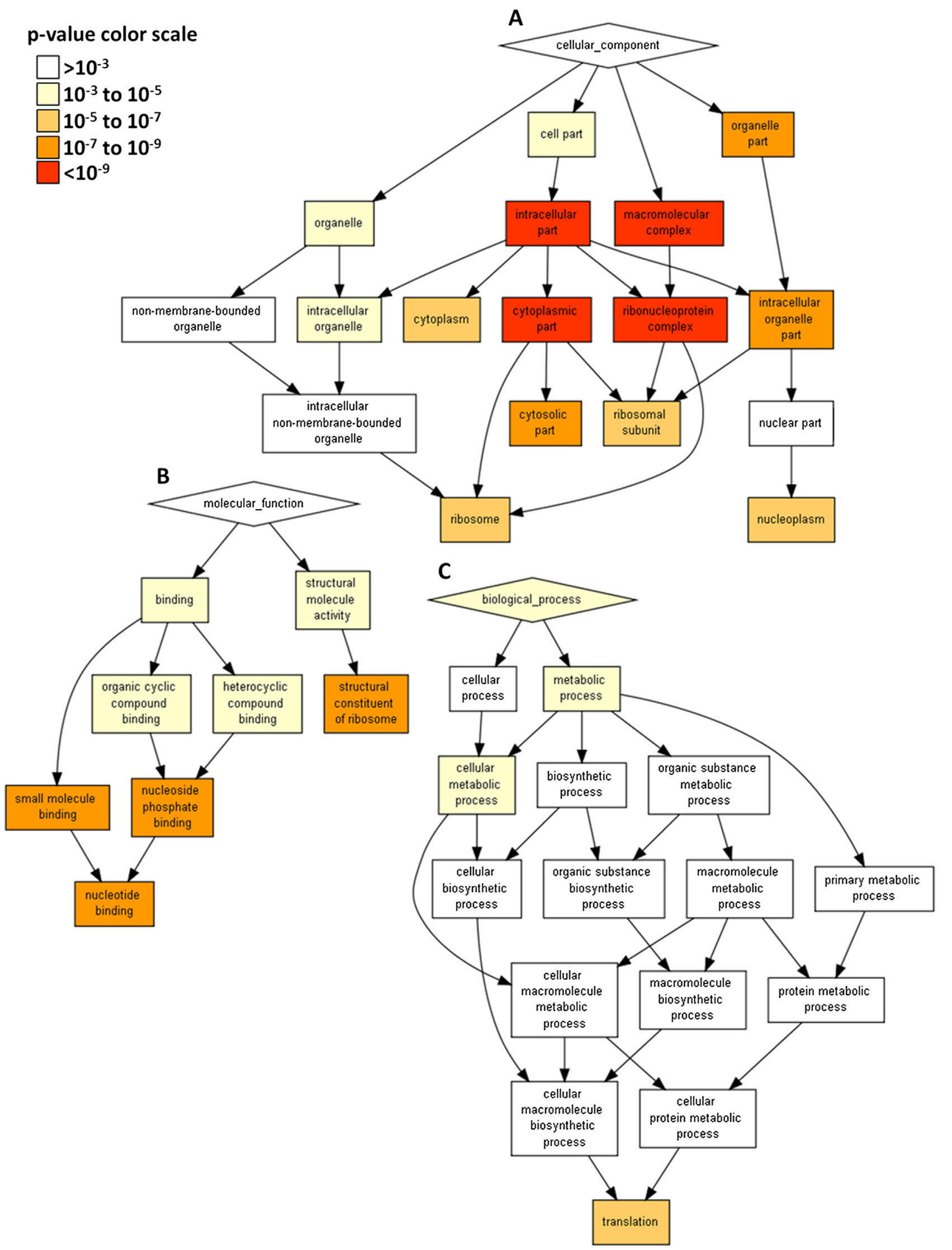

Fig. 4. Classes of proteins upregulated by BDNF in synaptoneurosomes isolated from cultured cortical neurons. The analysis was made based on the experimental data published by (Liao et al., 2007) and in comparison with the list of rat genes present in the Agilent Technologies Whole Rat Genome Microarray (https://earray.chem.agilent.com/earray/ catalogGeneLists.do?action=displaylist\#) using GOrilla. The results were grouped based on the following categories: "cellular component" (A), "molecular function" (B) and "biological process" (C). An enrichment was found in proteins related to RNP complexes and ribosomes (A), nucleotide binding and ribosomal functions (B), and translation processes (C). The results focus on the classes of proteins for which GO terms present a $p$-value lower than $10^{-5}$. 
is characterized by an expansion of the PSD and enlargement of the dendritic spines (Bosch and Hayashi, 2012). In addition to the effects on the cytoskeleton mediated by Arc, BDNF may also regulate the actin cytoskeleton through upregulation of RhoA protein levels, as described in synaptoneurosomes isolated from the mouse forebrain (Troca-Marin et al., 2010). RhoA is a regulator of actin polymerization (Luo, 2000), but it is not known whether the BDNFinduced upregulation of this member of the Rho GTPase family contributes to the effects of BDNF in synaptic plasticity.

Synaptic vesicle proteins and proteins related to their traffic were also shown to be upregulated by BDNF (Melo et al., 2013; Tartaglia et al., 2001; Thakker-Varia et al., 2001) (see Section 4.6), but additional studies are required to determine whether some of these alterations are extended to the synapse. Taken together, the BDNF-induced changes in the neuronal proteome described above suggest several putative mechanisms that may contribute to synaptic potentiation by BDNF.

\section{5. miRNAs as mediators of BDNF-induced alteration in the proteome}

miRNAs are non-coding RNAs that, together with RISC, repress the translation of target transcripts [for a review see (Chekulaeva and Filipowicz, 2009)]. It is increasingly evident that miRNAs post-transcriptionally regulate localized mRNAs (Konecna et al., 2009) and that some of the effects of BDNF in the central nervous system are mediated through alteration of their expression and/or activity (Table 1). The BDNF-induced synthesis of LIM domain kinase 1 (LIMK1) in dendrites through local relief of the activity of miR-134 in translation repression was the first demonstration that the synaptic effects of the neurotrophin could be mediated by regulation of miRNAs (Schratt et al., 2006). Interestingly, there is still residual BDNF induction of a reporter mRNA translation when miR-134 cannot bind LIMK1, suggesting the presence of additional mechanisms for regulation of BDNF-induced translation of LIMK1 (Schratt et al., 2006).
BDNF and synaptic activity were shown to increase the transcription of miR-134, which was coupled to the downregulation of Pumilio2 (Pum2) mRNA to promote dendritogenesis in hippocampal neurons (Fiore et al., 2009). Accordingly, neurons lacking Pum2 show enhanced dendritic arborization (Vessey et al., 2010). Pum2 is an RNA-binding protein present in discrete RNAcontaining particles, which negatively regulates eIF4E translation (Vessey et al., 2010). Interestingly, loss of Pumilio impairs long-term memory in Drosophila (Dubnau et al., 2003). In a separated study, miR-134 function was associated with synaptic plasticity and memory in rodents (Gao et al., 2010). The authors showed a role for SIRT1 in synaptic plasticity via miR-134-dependent regulation of cAMP-response element-binding protein (CREB) and BDNF expression (Gao et al., 2010). Altogether, miR-134 appears to be an important mediator of BDNF actions in the nervous system. BDNFinduced upregulation of miR-134 promotes dendritogenesis via downregulation of Pum2 mRNA (Fiore et al., 2009) whereas miR134 inactivation in dendrites upon BDNF stimulation is coupled to LIMK1 translation and spine growth (Schratt et al., 2006). Furthermore, miR-134 itself is able to regulate BDNF levels (Gao et al., 2010).

More recently, an embracing study demonstrated that the dual regulation of miRNAs biogenesis by the neurotrophin BDNF plays an important role in BDNF-induced protein synthesis (Huang et al., 2012). BDNF treatment induced a downregulation of the Let7-family of miRNAs through Lin28, and relieved the repression prompted by these miRNAs (Huang et al., 2012). In contrast, a general increase in miRNA biogenesis through Dicer was reported in response to BDNF stimulation and this dual regulation of miRNA biogenesis determines and confers selectivity to BDNFmediated protein synthesis (Huang et al., 2012). Although the presented mechanism occurs globally in the cell, the regulation of BDNF-induced translation by miRNAs most likely affect protein synthesis in different subcellular compartments such as in dendrites.

Table 1

Effects of BDNF on miRNA expression and functional implications.

\begin{tabular}{|c|c|c|c|}
\hline miRNA & Target mRNA & Regulation of miRNAs by BDNF and neuronal function & Ref. \\
\hline miR-134 & LIMK1 & $\begin{array}{l}\text { - Inactivated in dendrites. } \\
\text { - Regulates spine growth in cultured hippocampal neurons. }\end{array}$ & 1 \\
\hline miR379-410 cluster & Pum2 (via miR-134) & $\begin{array}{l}\text { - Increased miR-134 transcription through Mef2 activation. } \\
\text { - Promotes dendritogenesis in cultured hippocampal neurons. }\end{array}$ & 2 \\
\hline miR-132 & P250GAP & $\begin{array}{l}\text { - Highly induced. } \\
\text { - Promotes neurite outgrowth in cultured cortical neurons. }\end{array}$ & 3 \\
\hline miR-212/132 locus & - & $\begin{array}{l}\text { - Increased transcription via ERK1/2- and MSK1/2- dependent } \\
\text { and -independent mechanisms. }\end{array}$ & 4 \\
\hline miR-132 & - & $\begin{array}{l}\text { - Highly induced. } \\
\text { - Contributes to BDNF-dependent upregulation of glutamate } \\
\text { receptor subunits GluN2A, GluN2B and GluA1 in cultured } \\
\text { cortical neurons. }\end{array}$ & 5 \\
\hline miR-9 & MAP1b & $\begin{array}{l}\text { - Short- or long-term stimulation of axons with BDNF decreases } \\
\text { or increases axonal miR-9 levels, respectively. } \\
\text { - Regulates axon extension and branching in cultured cortical neurons. }\end{array}$ & 6 \\
\hline $\begin{array}{l}\text { Let-7a, } \\
\text { Let-7b, } \\
\text { Let-7F, } \\
\text { miR-107, } \\
\text { miR-143 } \\
\text { and others not described }\end{array}$ & - & $\begin{array}{l}\text { - General increase in miRNA biogenesis through activation of Dicer. } \\
\text { - Downregulation of Let-7 family members as well as miR-107 } \\
\text { and miR-143. } \\
\text { - Dual regulation of BDNF-induced protein synthesis } \\
\text { - Regulation of BDNF-dependent dendrite arborization. }\end{array}$ & 7 \\
\hline $\operatorname{miR}-375$ & HuD & - Inhibition of BDNF-induced neurite outgrowth in BE(2)-M17 cells. & 8 \\
\hline miR-125b & 10 putative targets identified & $\begin{array}{l}\text { - Upregulated. } \\
\text { - Promotes neurite outgrowth in SH-SY5Y cells. }\end{array}$ & 9 \\
\hline miR-124a & - & $\begin{array}{l}\text { - Upregulated. } \\
\text { - Promotes neurite outgrowth in SH-SY5Y cells. }\end{array}$ & 9 \\
\hline
\end{tabular}

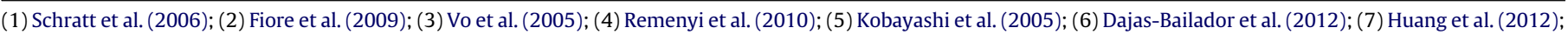

(8) Abdelmohsen et al. (2010); (9) Le et al. (2009). 
Additional studies identified other miRNAs regulated by BDNF. Application of this neurotrophin induces miR-125b and ectopic expression of miR-125b promotes neurite outgrowth in a human neuroblastoma cell line (Le et al., 2009). In a similar system, BDNFinduced neurite outgrowth was inhibited after silencing $\mathrm{HuD}$, a neuronal RNA-binding protein, or overexpressing miR-375 (Abdelmohsen et al., 2010). In addition, it was recently shown that miR-9 represses MAP1b translation and responds locally to BDNF to promote axon branching (Dajas-Bailador et al., 2012). Another miRNA under the regulation of BDNF is miR-132. This miRNA is induced in cultured cortical neurons by BDNF through the activation of CREB and enhances dendritic growth by inhibiting the translation of a GTPase-activating protein, P250GAP (Kawashima et al., 2010; Remenyi et al., 2010; Vo et al., 2005). Similarly, miR212 was shown to be upregulated in cortical neurons upon BDNF stimulation (Remenyi et al., 2010). The effect of BDNF on the upregulation of miR-132 and miR-212 was dependent on the activation of ERK pathway and the downstream MSK1 (mitogen- and stress-activated kinase 1) (Remenyi et al., 2010). Importantly, blocking the endogenous miR-132 results in a decrease of BDNFdependent upregulation of several synaptic proteins such as the glutamate receptor subunits GluN2A, GluN2B and GluA1 (Kawashima et al., 2010). The direct targets of miR-132 that contribute for BDNF regulation of glutamate receptors remain to be identified.

Interestingly, increasing evidence suggest a role for miR-132 in plasticity-related events. This miRNA was shown to modulate short-term plasticity, without affecting basal synaptic transmission, in hippocampal neurons (Lambert et al., 2010), and to play a critical role in the experience-dependent plasticity of visual cortex circuits (Mellios et al., 2011; Tognini et al., 2011). A different study showed a differential regulation of primary and mature miR-132/212 expression following LTP induction in vivo (Wibrand et al., 2010). In this context, blockade of NMDA receptor-dependent LTP enhanced the expression of mature miR-132 whereas blocking the mGluR-dependent signaling prevented the LTP-induced expression of this miRNA (Wibrand et al., 2010). Furthermore, miR-132 was shown to be strongly induced following general pharmacological and physiological neuronal activation in vivo (Nudelman et al., 2010). miR-132 also modulates dendritic plasticity and synaptic maturation by controlling the expression of methyl CPG-binding protein 2 (MeCP2) (Klein et al., 2007). The authors demonstrated the ability of miR-132 to repress MeCP2 translation and observed an increase in BDNF levels when miR-132-mediated repression of MeCP2 was blocked (Klein et al., 2007). These results, together with the previous reports showing the upregulation of miR-132 by BDNF (Kawashima et al., 2010; Remenyi et al., 2010; Vo et al., 2005), suggest a homeostatic mechanism for maintaining MeCP2 levels. In fact, keeping MeCP2 expression precisely at the right levels is essential for the proper neuronal development (Fukuda et al., 2005; Jugloff et al., 2005).

Together, the available data suggest a critical role for BDNFregulated miRNAs in the regulation of neuronal development and function. Future research is needed to clarify the mechanisms mediating miRNAs synthesis, trafficking and actions in central nervous system. It will be of great interest to develop methodologies that allow the simultaneous observation of miRNAs and their targets in living systems. Interestingly, it was reported that the entire molecular machinery necessary for miRNAs biogenesis is present near synapses (Lugli et al., 2012) supporting the idea that miRNA synthesis may occur locally. If so, it would be important to investigate the nature of the different pools of miRNAs at the synapse (locally synthesized vs transported) and determine which of those, or if both, account for the role of BDNF in synaptic regulation.

\subsection{BDNF-induced changes in the transcription activity and the synaptic proteome}

The role of BDNF in the L-LTP, which is dependent on transcription activity, suggests that changes in gene expression underlie some of the effects of the neurotrophin. This hypothesis is based on studies showing induction of LTP by exogenously applied BDNF at the medial perforant path-granule cell synapses in vivo (Messaoudi et al., 1998), an effect that is blocked by the transcription inhibitor actinomycin D (Messaoudi et al., 2002). Furthermore, BDNF induces the expression of genes coding for regulators of synaptic activity, such as Arc (Ying et al., 2002; Zheng et al., 2009) and several synaptic vesicle proteins, including vesicular glutamate transporters (Melo et al., 2013; Tartaglia et al., 2001). However, the role of BDNF in transcription regulation has been addressed mainly using bath application of the neurotrophin, which does not allow distinguishing the localization of the TrkB receptors involved in the control of gene expression.

A recent study using a microfluidic device that allows the isolation of the dendritic compartment showed that BDNF acts on dendrites of cultured cortical neurons to induce an signal that upregulates the expression of the IEG Arc and c-Fos (Cohen et al., 2011) (Fig. 1). The effect of BDNF in the signaling from dendrites to the nucleus depends on MEK1/2 (MAPK and ERK kinase, type 1/ 2 ), and activity of the TrkB receptors to induce gene expression is required mainly in the soma compartment. However, distinct mechanisms are involved in the regulation of the expression of the two genes since the $\mathrm{Ca}^{2+}$ concentration in the soma and in the dendritic compartments influenced the expression of Arc but not cFos (Cohen et al., 2011). Additional studies are required to identify other genes that are specifically regulated following activation of dendritic receptors for BDNF. Whether these BDNF-induced transcripts coding for synaptic proteins are mainly translated in the soma before being transported to dendrites and/or delivered to the dendritic compartment in RNA granules also remains to be elucidated. To contribute to the long-term potentiation of the synapse that was initially stimulated, the newly synthesized mRNAs or the translated proteins should be targeted to a specific synapse. The proteins locally translated at the synapse in response to BDNF stimulation could function in the capture of the neurotrophininduced RNA granules or proteins traveling along dendrites, as predicted by the synaptic tagging and capture hypothesis (Redondo and Morris, 2011), but this remains to be investigated.

Long-term treatment of hippocampal slice cultures with BDNF was shown to upregulate synaptophysin, synaptobrevin and synaptotagmin protein levels (Tartaglia et al., 2001). Furthermore, incubation of cultured hippocampal neurons with the neurotrophin upregulates the vesicular glutamate transporter protein levels, as well as the clustering of the transporters along neurites (Melo et al., 2013). However, at this point it is not possible to predict whether these effects may play a role in synaptic potentiation by BDNF because, as discussed above, no attempt has been made to specifically address the effect of axonal stimulation with BDNF. It remains to be determined whether activation of presynaptic TrkB receptors by BDNF, which is followed by the transport of TrkB-BDNF complexes as part of signaling endosomes (Ha et al., 2008; Watson et al., 2001; Xie et al., 2012; Ye et al., 2003), upregulates the expression of genes coding for presynaptic proteins. If this is the case, the newly synthesized proteins could be then delivered to the synapse, thereby contributing to an upregulating of glutamate release. The anterograde axonal transport of the proteins may be further enhanced by upregulating KIF1A (Kondo et al., 2012), a motor protein involved in the transport of synaptic vesicle precursors, including synaptophysin, synaptotagmin and Rab3A (Okada et al., 1995; Yonekawa et al., 1998). Future studies are required to fully 
understand the role of this pathway in the L-LTP and the mechanisms involved.

\section{Concluding remarks}

Although the role of BDNF in LTP in the hippocampus and in other brain regions is well established, the molecular mechanisms involved are still poorly understood. The recent identification of a large number of dendritic transcripts should contribute to elucidate the role of local translation induced by BDNF in LTP, but additional studies are still required to characterize the mechanisms whereby different mRNAs are transported along dendrites and how the traffic is regulated. Also, considering the diversity of structures that may be involved in the transport of mRNAs, it will be important to determine whether a common mechanism is involved in the recruitment of transcripts for translation. With a growing number of proteins identified as being translated at the synapse, it is important to determine the relative contribution of local translation vs. protein traffic from the soma to the late phase of LTP, in particular in response to BDNF stimulation. Furthermore, given the evidence suggesting that miRNAs can be synthesized locally at the synapse, it is reasonable to hypothesize that dendritic miRNAs synthesis may provide a new layer for local BDNF regulation and contribute to the role of BDNF in synaptic plasticity. Finally, with the recent findings showing a BDNF-induced signal traveling from dendrites to the soma to regulate gene expression, it will be important to determine how proteins produced in the soma in response to this signal target specifically the activated synapse, and whether a similar mechanism operates for mRNAs.

\section{Acknowledgments}

The work in the authors laboratory is funded by Fundação para a Ciência e Tecnologia, COMPETE (Programa Operacional Factores de Competitividade), QREN and FEDER (Fundo Europeu de Desenvolvimento Regional) (PTDC/SAU-NEU/104297/2008, PTDC/SAU-NMC/ $120144 / 2010$ and PEst-C/SAU/LA0001/2011).

\section{Appendix A. Supplementary data}

Supplementary data related to this article can be found at http:// dx.doi.org/10.1016/j.neuropharm.2013.04.005.

\section{References}

Aakalu, G., Smith, W.B., Nguyen, N., Jiang, C., Schuman, E.M., 2001. Dynamic visualization of local protein synthesis in hippocampal neurons. Neuron 30, 489-502.

Abdelmohsen, K., Hutchison, E.R., Lee, E.K., Kuwano, Y., Kim, M.M., Masuda, K., Srikantan, S., Subaran, S.S., Marasa, B.S., Mattson, M.P., Gorospe, M., 2010. miR375 inhibits differentiation of neurites by lowering HuD levels. Mol. Cell. Biol. 30, 4197-4210.

Aid, T., Kazantseva, A., Piirsoo, M., Palm, K., Timmusk, T., 2007. Mouse and rat BDNF gene structure and expression revisited. J. Neurosci. Res. 85, 525-535.

Alder, J., Thakker-Varia, S., Crozier, R.A., Shaheen, A., Plummer, M.R., Black, I.B., 2005. Early presynaptic and late postsynaptic components contribute independently to brain-derived neurotrophic factor-induced synaptic plasticity. J. Neurosci. 25, 3080-3085.

Alonso, M., Medina, J.H., Pozzo-Miller, L., 2004. ERK1/2 activation is necessary for BDNF to increase dendritic spine density in hippocampal CA1 pyramidal neurons. Learn. Mem. 11, 172-178.

Amaral, M.D., Pozzo-Miller, L., 2007. TRPC3 channels are necessary for brainderived neurotrophic factor to activate a nonselective cationic current and to induce dendritic spine formation. J. Neurosci. 27, 5179-5189.

An, J.J., Gharami, K., Liao, G.Y., Woo, N.H., Lau, A.G., Vanevski, F., Torre, E.R., Jones, K.R., Feng, Y., Lu, B., Xu, B., 2008. Distinct role of long 3' UTR BDNF mRNA in spine morphology and synaptic plasticity in hippocampal neurons. Cell 134, 175-187.

Anderson, P., Kedersha, N., 2006. RNA granules. J. Cell. Biol. 172, 803-808.

Andreassi, C., Riccio, A., 2009. To localize or not to localize: mRNA fate is in 3'UTR ends. Trends Cell. Biol. 19, 465-474.
Baj, G., Leone, E., Chao, M.V., Tongiorgi, E., 2011. Spatial segregation of BDNF transcripts enables BDNF to differentially shape distinct dendritic compartments. Proc. Natl. Acad. Sci. U. S. A. 108, 16813-16818.

Bassell, G.J., Warren, S.T., 2008. Fragile X syndrome: loss of local mRNA regulation alters synaptic development and function. Neuron 60, 201-214.

Batish, M., van den Bogaard, P., Kramer, F.R., Tyagi, S., 2012. Neuronal mRNAs travel singly into dendrites. Proc. Natl. Acad. Sci. U. S. A. 109, 4645-4650.

Belelovsky, K., Elkobi, A., Kaphzan, H., Nairn, A.C., Rosenblum, K., 2005. A molecular switch for translational control in taste memory consolidation. Eur. J. Neurosci. 22, 2560-2568.

Blichenberg, A., Rehbein, M., Muller, R., Garner, C.C., Richter, D., Kindler, S., 2001. Identification of a cis-acting dendritic targeting element in the mRNA encoding the alpha subunit of $\mathrm{Ca}^{2+} /$ calmodulin-dependent protein kinase II. Eur. J. Neurosci. 13, 1881-1888.

Bockers, T.M., Segger-Junius, M., Iglauer, P., Bockmann, J., Gundelfinger, E.D. Kreutz, M.R., Richter, D., Kindler, S., Kreienkamp, H.J., 2004. Differential expression and dendritic transcript localization of Shank family members: identification of a dendritic targeting element in the 3' untranslated region of Shank1 mRNA. Mol. Cell. Neurosci. 26, 182-190.

Bosch, M., Hayashi, Y., 2012. Structural plasticity of dendritic spines. Curr. Opin. Neurobiol. 22, 383-388.

Bramham, C.R., Alme, M.N., Bittins, M., Kuipers, S.D., Nair, R.R., Pai, B., Panja, D. Schubert, M., Soule, J., Tiron, A., Wibrand, K., 2010. The Arc of synaptic memory. Exp. Brain Res. 200, 125-140.

Bramham, C.R., Messaoudi, E., 2005. BDNF function in adult synaptic plasticity: the synaptic consolidation hypothesis. Prog. Neurobiol. 76, 99-125.

Bramham, C.R., Wells, D.G., 2007. Dendritic mRNA: transport, translation and function. Nat. Rev. Neurosci. 8, 776-789.

Cajigas, I.J., Tushev, G., Will, T.J., tom Dieck, S., Fuerst, N., Schuman, E.M., 2012. The local transcriptome in the synaptic neuropil revealed by deep sequencing and high-resolution imaging. Neuron 74, 453-466.

Caldeira, M.V., Melo, C.V., Pereira, D.B., Carvalho, R., Correia, S.S., Backos, D.S. Carvalho, A.L., Esteban, J.A., Duarte, C.B., 2007a. Brain-derived neurotrophic factor regulates the expression and synaptic delivery of alpha-amino-3 hydroxy-5-methyl-4-isoxazole propionic acid receptor subunits in hippocampal neurons. J. Biol. Chem. 282, 12619-12628.

Caldeira, M.V., Melo, C.V., Pereira, D.B., Carvalho, R.F, Carvalho, A.L, Duarte, C.B. 2007b. BDNF regulates the expression and traffic of NMDA receptors in cultured hippocampal neurons. Mol. Cell. Neurosci. 35, 208-219.

Carvalho, A.L., Caldeira, M.V., Santos, S.D., Duarte, C.B., 2008. Role of the brainderived neurotrophic factor at glutamatergic synapses. Br. J. Pharmacol. 153 (Suppl. 1), S310-S324.

Chekulaeva, M., Filipowicz, W., 2009. Mechanisms of miRNA-mediated post-transcriptional regulation in animal cells. Curr. Opin. Cell. Biol. 21, 452-460.

Chen, G., Kolbeck, R., Barde, Y.A., Bonhoeffer, T., Kossel, A., 1999. Relative contribution of endogenous neurotrophins in hippocampal long-term potentiation. J. Neurosci. 19, 7983-7990.

Chen, L.Y., Rex, C.S., Casale, M.S., Gall, C.M., Lynch, G., 2007. Changes in synaptic morphology accompany actin signaling during LTP. J. Neurosci. 27, 5363-5372.

Chiaruttini, C., Sonego, M., Baj, G., Simonato, M., Tongiorgi, E., 2008. BDNF mRNA splice variants display activity-dependent targeting to distinct hippocampal laminae. Mol. Cell. Neurosci. 37, 11-19.

Chiaruttini, C., Vicario, A., Li, Z., Baj, G., Braiuca, P., Wu, Y., Lee, F.S., Gardossi, L., Baraban, J.M., Tongiorgi, E., 2009. Dendritic trafficking of BDNF mRNA is mediated by translin and blocked by the G196A (Val66Met) mutation. Proc. Natl. Acad. Sci. U. S. A. 106, 16481-16486.

Chotiner, J.K., Khorasani, H., Nairn, A.C., O'Dell, T.J., Watson, J.B., 2003. Adenylyl cyclase-dependent form of chemical long-term potentiation triggers translational regulation at the elongation step. Neuroscience 116, 743-752.

Cohen, M.S., Bas Orth, C., Kim, H.J., Jeon, N.L., Jaffrey, S.R., 2011. Neurotrophinmediated dendrite-to-nucleus signaling revealed by microfluidic compartmentalization of dendrites. Proc. Natl. Acad. Sci. U. S. A. 108, 11246-11251.

Costa-Mattioli, M., Sossin, W.S., Klann, E., Sonenberg, N., 2009. Translational control of long-lasting synaptic plasticity and memory. Neuron $61,10-26$

Cougot, N., Bhattacharyya, S.N., Tapia-Arancibia, L., Bordonne, R., Filipowicz, W. Bertrand, E., Rage, F., 2008. Dendrites of mammalian neurons contain specialized P-body-like structures that respond to neuronal activation. J. Neurosci. 28 13793-13804.

Cowansage, K.K., LeDoux, J.E., Monfils, M.H., 2010. Brain-derived neurotrophic factor: a dynamic gatekeeper of neural plasticity. Curr. Mol. Pharmacol. 3, 1229.

Dajas-Bailador, F., Bonev, B., Garcez, P., Stanley, P., Guillemot, F., Papalopulu, N., 2012. microRNA-9 regulates axon extension and branching by targeting Map1b in mouse cortical neurons. Nat. Neurosci. 15, 697-699.

Darnell, J.C., Van Driesche, S.J., Zhang, C., Hung, K.Y., Mele, A., Fraser, C.E., Stone, E.F. Chen, C., Fak, J.J., Chi, S.W., Licatalosi, D.D., Richter, J.D., Darnell, R.B., 2011. FMRP stalls ribosomal translocation on mRNAs linked to synaptic function and autism. Cell 146, 247-261.

di Penta, A., Mercaldo, V., Florenzano, F., Munck, S., Ciotti, M.T., Zalfa, F., Mercanti, D. Molinari, M., Bagni, C., Achsel, T., 2009. Dendritic LSm1/CBP80-mRNPs mark the early steps of transport commitment and translational control. J. Cell. Biol. 184, $423-435$.

Dictenberg, J.B., Swanger, S.A., Antar, L.N., Singer, R.H., Bassell, G.J., 2008. A direct role for FMRP in activity-dependent dendritic mRNA transport links filopodialspine morphogenesis to fragile X syndrome. Dev. Cell. 14, 926-939. 
Doyle, M., Kiebler, M.A., 2011. Mechanisms of dendritic mRNA transport and its role in synaptic tagging. EMBO J. 30, 3540-3552.

Drake, C.T., Milner, T.A., Patterson, S.L., 1999. Ultrastructural localization of fulllength trkB immunoreactivity in rat hippocampus suggests multiple roles in modulating activity-dependent synaptic plasticity. J. Neurosci. 19, 8009-8026.

Dubnau, J., Chiang, A.S., Grady, L., Barditch, J., Gossweiler, S., McNeil, J., Smith, P., Buldoc, F., Scott, R., Certa, U., Broger, C., Tully, T., 2003. The staufen/pumilio pathway is involved in Drosophila long-term memory. Curr. Biol. 13, 286-296.

Duchaine, TF, Hemraj, I, Furic, L, Deitinghoff, A Kiebler, M.A., DesGroseillers, L, 2002. Staufen 2 isoforms localize to the somatodendritic domain of neurons and interact with different organelles. J. Cell. Sci. 115, 3285-3295.

Eberwine, J., Miyashiro, K., Kacharmina, J.E., Job, C., 2001. Local translation of classes of mRNAs that are targeted to neuronal dendrites. Proc. Natl. Acad. Sci. U. S. A. 98, 7080-7085.

Edbauer, D., Neilson, J.R., Foster, K.A., Wang, C.F., Seeburg, D.P., Batterton, M.N., Tada, T., Dolan, B.M., Sharp, P.A., Sheng, M., 2010. Regulation of synaptic structure and function by FMRP-associated microRNAs miR-125b and miR-132. Neuron 65, 373-384.

Eden, E., Navon, R., Steinfeld, I., Lipson, D., Yakhini, Z., 2009. GOrilla: a tool for discovery and visualization of enriched GO terms in ranked gene lists. BMC Bioinformatics 10, 48.

Egan, M.F., Kojima, M., Callicott, J.H., Goldberg, T.E., Kolachana, B.S., Bertolino, A. Zaitsev, E., Gold, B., Goldman, D., Dean, M., Lu, B., Weinberger, D.R., 2003. The BDNF val66met polymorphism affects activity-dependent secretion of BDNF and human memory and hippocampal function. Cell 112, 257-269.

Elvira, G., Wasiak, S., Blandford, V., Tong, X.K., Serrano, A., Fan, X., del Rayo SanchezCarbente, M., Servant, F., Bell, A.W., Boismenu, D., Lacaille, J.C., McPherson, P.S. DesGroseillers, L., Sossin, W.S., 2006. Characterization of an RNA granule from developing brain. Mol. Cell. Proteomics 5, 635-651.

Eom, T., Antar, L.N., Singer, R.H., Bassell, G.J., 2003. Localization of a beta-actin messenger ribonucleoprotein complex with zipcode-binding protein modulates the density of dendritic filopodia and filopodial synapses. J. Neurosci. 23 10433-10444.

Falley, K., Schutt, J., Iglauer, P., Menke, K., Maas, C., Kneussel, M., Kindler, S Wouters, F.S., Richter, D., Kreienkamp, H.J., 2009. Shank1 mRNA: dendritic transport by kinesin and translational control by the 5 ' untranslated region. Traffic 10, 844-857.

Figurov, A., Pozzo-Miller, L.D., Olafsson, P., Wang, T., Lu, B., 1996. Regulation of synaptic responses to high-frequency stimulation and LTP by neurotrophins in the hippocampus. Nature 381, 706-709.

Fiore, R., Khudayberdiev, S., Christensen, M., Siegel, G., Flavell, S.W., Kim, T.K. Greenberg, M.E., Schratt, G., 2009. Mef2-mediated transcription of the miR379410 cluster regulates activity-dependent dendritogenesis by fine-tuning Pumilio2 protein levels. EMBO J. 28, 697-710.

Fortin, D.A., Srivastava, T., Dwarakanath, D., Pierre, P., Nygaard, S., Derkach, V.A., Soderling, T.R., 2012. Brain-derived neurotrophic factor activation of CaMkinase kinase via transient receptor potential canonical channels induces the translation and synaptic incorporation of GluA1-containing calcium-permeable AMPA receptors. J. Neurosci. 32, 8127-8137.

Fukazawa, Y., Saitoh, Y., Ozawa, F., Ohta, Y., Mizuno, K., Inokuchi, K., 2003. Hippocampal LTP is accompanied by enhanced F-actin content within the dendritic spine that is essential for late LTP maintenance in vivo. Neuron 38 $447-460$

Fukuda, T., Itoh, M., Ichikawa, T., Washiyama, K., Goto, Y., 2005. Delayed maturation of neuronal architecture and synaptogenesis in cerebral cortex of Mecp2deficient mice. J. Neuropathol. Exp. Neurol. 64, 537-544.

Fumagalli, S., Thomas, G., 2000. S6 phosphorylation and signal transduction. In: Sonenberg, N., Hershey, J.W.B., Mathews, M.B. (Eds.), Translation Control of Gene Expression. Cold Spring Harbor Laboratory Press, Cold Spring Harbor, New York, pp. 695-718.

Gao, J., Wang, W.Y., Mao, Y.W., Graff, J., Guan, J.S., Pan, L., Mak, G., Kim, D., Su, S.C. Tsai, L.H., 2010. A novel pathway regulates memory and plasticity via SIRT1 and miR-134. Nature 466, 1105-1109.

Gao, Y., Tatavarty, V., Korza, G., Levin, M.K., Carson, J.H., 2008. Multiplexed dendritic targeting of alpha calcium calmodulin-dependent protein kinase II, neurogranin, and activity-regulated cytoskeleton-associated protein RNAs by the A2 pathway. Mol. Biol. Cell. 19, 2311-2327.

Gartner, A., Polnau, D.G., Staiger, V., Sciarretta, C., Minichiello, L., Thoenen, H. Bonhoeffer, T. Korte, M., 2006. Hippocampal long-term potentiation is supported by presynaptic and postsynaptic tyrosine receptor kinase B-mediated phospholipase C gamma signaling. J. Neurosci. 26, 3496-3504.

Gingras, A.C., Raught, B., Sonenberg, N., 2004. mTOR signaling to translation. Curr Top. Microbiol. Immunol. 279, 169-197.

Giorgi, C., Moore, M.J., 2007. The nuclear nurture and cytoplasmic nature of localized mRNPs. Semin. Cell. Dev. Biol. 18, 186-193.

Giorgi, C., Yeo, G.W., Stone, M.E., Katz, D.B., Burge, C., Turrigiano, G., Moore, M.J. 2007. The EJC factor eIF4AIII modulates synaptic strength and neuronal protein expression. Cell 130, 179-191.

Glanzer, J., Miyashiro, K.Y., Sul, J.Y., Barrett, L., Belt, B., Haydon, P., Eberwine, J., 2005. RNA splicing capability of live neuronal dendrites. Proc. Natl. Acad. Sci. U. S. A $102,16859-16864$

Gruart, A., Sciarretta, C., Valenzuela-Harrington, M., Delgado-Garcia, J.M., Minichiello, L., 2007. Mutation at the TrkB PLC\{gamma\}-docking site affects hippocampal LTP and associative learning in conscious mice. Learn. Mem. 14, 54-62.
Gu, W., Pan, F., Zhang, H., Bassell, G.J., Singer, R.H., 2002. A predominantly nuclear protein affecting cytoplasmic localization of beta-actin mRNA in fibroblasts and neurons. J. Cell. Biol. 156, 41-51.

Guire, E.S., Oh, M.C., Soderling, T.R., Derkach, V.A., 2008. Recruitment of calciumpermeable AMPA receptors during synaptic potentiation is regulated by CaMkinase I. J. Neurosci. 28, 6000-6009.

Guzowski, J.F., Lyford, G.L., Stevenson, G.D., Houston, F.P., McGaugh, J.L., Worley, P.F., Barnes, C.A., 2000. Inhibition of activity-dependent arc protein expression in the rat hippocampus impairs the maintenance of long-term potentiation and the consolidation of long-term memory. J. Neurosci. 20 3993-4001.

Ha, J., Lo, K.W., Myers, K.R., Carr, T.M., Humsi, M.K., Rasoul, B.A., Segal, R.A., Pfister, K.K., 2008. A neuron-specific cytoplasmic dynein isoform preferentially transports TrkB signaling endosomes. J. Cell. Biol. 181, 1027-1039.

Herb, A., Wisden, W., Catania, M.V., Marechal, D., Dresse, A., Seeburg, P.H., 1997. Prominent dendritic localization in forebrain neurons of a novel mRNA and its product, dendrin. Mol. Cell. Neurosci. 8, 367-374.

Herbert, T.P., Proud, C.G., 2007. Regulation of translation elongation and the cotranslational protein targeting pathway. In: Mathews, M.B. Sonenberg, N., Hershey, J.W.B. (Eds.), Translational Control in Biology and Medicine. Cold Spring Harbor Laboratory Press, Cold Spring Harbor, New York, pp. 601-624.

Huang, Y.S., Carson, J.H., Barbarese, E., Richter, J.D., 2003. Facilitation of dendritic mRNA transport by CPEB. Genes Dev. 17, 638-653.

Huang, Y.W., Ruiz, C.R., Eyler, E.C., Lin, K., Meffert, M.K., 2012. Dual regulation of miRNA biogenesis generates target specificity in neurotrophin-induced protein synthesis. Cell 148, 933-946.

Huttelmaier, S., Zenklusen, D., Lederer, M., Dictenberg, J., Lorenz, M., Meng, X., Bassell, G.J., Condeelis, J., Singer, R.H., 2005. Spatial regulation of beta-actin translation by Src-dependent phosphorylation of ZBP1. Nature 438, 512-515.

Inamura, N., Nawa, H., Takei, N., 2005. Enhancement of translation elongation in neurons by brain-derived neurotrophic factor: implications for mammalian target of rapamycin signaling. J. Neurochem. 95, 1438-1445.

Jeong, J.H., Nam, Y.J., Kim, S.Y., Kim, E.G., Jeong, J., Kim, H.K., 2007. The transport of Staufen2-containing ribonucleoprotein complexes involves kinesin motor protein and is modulated by mitogen-activated protein kinase pathway. J. Neurochem. 102, 2073-2084.

Ji, Y., Lu, Y., Yang, F., Shen, W., Tang, T.T., Feng, L., Duan, S., Lu, B., 2010. Acute and gradual increases in BDNF concentration elicit distinct signaling and functions in neurons. Nat. Neurosci. 13, 302-309.

Jourdi, H., Iwakura, Y., Narisawa-Saito, M., Ibaraki, K., Xiong, H., Watanabe, M. Hayashi, Y., Takei, N., Nawa, H., 2003. Brain-derived neurotrophic factor signal enhances and maintains the expression of AMPA receptor-associated PDZ proteins in developing cortical neurons. Dev. Biol. 263, 216-230.

Jovanovic, J.N., Czernik, A.J., Fienberg, A.A., Greengard, P., Sihra, T.S., 2000. Synapsins as mediators of BDNF-enhanced neurotransmitter release. Nat. Neurosci. 3, 323-329.

Jugloff, D.G., Jung, B.P., Purushotham, D., Logan, R., Eubanks, J.H., 2005 Increased dendritic complexity and axonal length in cultured mouse cortical neurons overexpressing methyl-CpG-binding protein MeCP2. Neurobiol. Dis. 19, 18-27.

Jung, M.Y., Lorenz, L., Richter, J.D., 2006. Translational control by neuroguidin, a eukaryotic initiation factor $4 \mathrm{E}$ and $\mathrm{CPEB}$ binding protein. Mol. Cell. Biol. 26, 4277-4287.

Kanai, Y., Dohmae, N., Hirokawa, N., 2004. Kinesin transports RNA: isolation and characterization of an RNA-transporting granule. Neuron 43, 513-525.

Kandel, E.R., 2001. The molecular biology of memory storage: a dialogue between genes and synapses. Science 294, 1030-1038.

Kang, H., Schuman, E.M., 1996. A requirement for local protein synthesis in neurotrophin-induced hippocampal synaptic plasticity. Science 273, 1402-1406.

Kang, H., Welcher, A.A., Shelton, D., Schuman, E.M., 1997. Neurotrophins and time: different roles for TrkB signaling in hippocampal long-term potentiation. Neuron 19, 653-664.

Kanhema, T., Dagestad, G., Panja, D., Tiron, A., Messaoudi, E., Havik, B., Ying, S.W. Nairn, A.C., Sonenberg, N., Bramham, C.R., 2006. Dual regulation of translation initiation and peptide chain elongation during BDNF-induced LTP in vivo: evidence for compartment-specific translation control. J. Neurochem. 99, 1328-1337.

Kasai, H., Fukuda, M., Watanabe, S., Hayashi-Takagi, A., Noguchi, J., 2010. Structural dynamics of dendritic spines in memory and cognition. Trends Neurosci. 33, 121-129.

Kawashima, H., Numakawa, T., Kumamaru, E., Adachi, N., Mizuno, H., Ninomiya, M., Kunugi, H., Hashido, K., 2010. Glucocorticoid attenuates brain-derived neurotrophic factor-dependent upregulation of glutamate receptors via the suppression of microRNA-132 expression. Neuroscience 165, 1301-1311.

Kelleher 3rd, R.J., Govindarajan, A., Jung, H.Y., Kang, H., Tonegawa, S., 2004. Translational control by MAPK signaling in long-term synaptic plasticity and memory. Cell 116, 467-479.

Kiebler, M.A., Bassell, G.J., 2006. Neuronal RNA granules: movers and makers. Neuron 51, 685-690.

Kiebler, M.A., Hemraj, I., Verkade, P., Kohrmann, M., Fortes, P., Marion, R.M., Ortin, J., Dotti, C.G., 1999. The mammalian staufen protein localizes to the somatodendritic domain of cultured hippocampal neurons: implications for its involvement in mRNA transport. J. Neurosci. 19, 288-297. 
Kim, Y.K., Furic, L., Desgroseillers, L., Maquat, L.E., 2005. Mammalian Staufen1 recruits Upf1 to specific mRNA 3'UTRs so as to elicit mRNA decay. Cell 120, 195-208.

Kislauskis, E.H., Zhu, X., Singer, R.H., 1994. Sequences responsible for intracellular localization of beta-actin messenger RNA also affect cell phenotype. J. Cell. Biol. 127, 441-451.

Klein, M.E., Lioy, D.T., Ma, L., Impey, S., Mandel, G., Goodman, R.H., 2007. Homeostatic regulation of $\mathrm{MeCP} 2$ expression by a CREB-induced microRNA. Nat. Neurosci. 10, 1513-1514.

Klein, M.E., Younts, T.J., Castillo, P.E., Jordan, B.A., 2013. RNA-binding protein Sam68 controls synapse number and local beta-actin mRNA metabolism in dendrites. Proc. Natl. Acad. Sci. U. S. A. 110, 3125-3130.

Knowles, R.B., Sabry, J.H., Martone, M.E., Deerinck, T.J., Ellisman, M.H., Bassell, G.J., Kosik, K.S., 1996. Translocation of RNA granules in living neurons. J. Neurosci. 16, 7812-7820.

Kobayashi, H., Yamamoto, S., Maruo, T., Murakami, F., 2005. Identification of a cisacting element required for dendritic targeting of activity-regulated cytoskeleton-associated protein mRNA. Eur. J. Neurosci. 22, 2977-2984.

Kondo, M., Takei, Y., Hirokawa, N., 2012. Motor protein KIF1A is essential for hippocampal synaptogenesis and learning enhancement in an enriched environment. Neuron 73, 743-757.

Konecna, A., Heraud, J.E., Schoderboeck, L., Raposo, A.A., Kiebler, M.A., 2009. What are the roles of microRNAs at the mammalian synapse? Neurosci. Lett. 466, 63-68.

Korte, M., Carroll, P., Wolf, E., Brem, G., Thoenen, H., Bonhoeffer, T., 1995. Hippocampal long-term potentiation is impaired in mice lacking brain-derived neurotrophic factor. Proc. Natl. Acad. Sci. U. S. A. 92, 8856-8860.

Korte, M., Kang, H., Bonhoeffer, T., Schuman, E., 1998. A role for BDNF in the latephase of hippocampal long-term potentiation. Neuropharmacology 37, 553559.

Korte, M., Staiger, V., Griesbeck, O., Thoenen, H., Bonhoeffer, T., 1996. The involvement of brain-derived neurotrophic factor in hippocampal long-term potentiation revealed by gene targeting experiments. J. Physiol. Paris 90, 157-164.

Kovalchuk, Y., Hanse, E., Kafitz, K.W., Konnerth, A., 2002. Postsynaptic induction of BDNF-mediated long-term potentiation. Science 295, 1729-1734.

Lambert, T.J., Storm, D.R., Sullivan, J.M., 2010. MicroRNA132 modulates short-term synaptic plasticity but not basal release probability in hippocampal neurons. PLoS One 5, e15182.

Le, M.T., Xie, H., Zhou, B., Chia, P.H., Rizk, P., Um, M., Udolph, G., Yang, H., Lim, B., Lodish, H.F., 2009. MicroRNA-125b promotes neuronal differentiation in human cells by repressing multiple targets. Mol. Cell. Biol. 29, 5290-5305.

Lebeau, G., Maher-Laporte, M., Topolnik, L., Laurent, C.E., Sossin, W., Desgroseillers, L., Lacaille, J.C., 2008. Staufen1 regulation of protein synthesisdependent long-term potentiation and synaptic function in hippocampal pyramidal cells. Mol. Cell. Biol. 28, 2896-2907.

Lebeau, G., Miller, L.C., Tartas, M., McAdam, R., Laplante, I., Badeaux, F., DesGroseillers, L., Sossin, W.S., Lacaille, J.C., 2011. Staufen 2 regulates mGluR long-term depression and Map1b mRNA distribution in hippocampal neurons. Learn. Mem. 18, 314-326.

Lein, E.S., Hawrylycz, M.J., Ao, N., Ayres, M., Bensinger, A., Bernard, A., Boe, A.F., Boguski, M.S., Brockway, K.S., Byrnes, E.J., Chen, L., Chen, T.M., Chin, M.C., Chong, J., Crook, B.E., Czaplinska, A., Dang, C.N., Datta, S., Dee, N.R., Desaki, A.L., Desta, T., Diep, E., Dolbeare, T.A., Donelan, M.J., Dong, H.W., Dougherty, J.G., Duncan, B.J., Ebbert, A.J., Eichele, G., Estin, L.K., Faber, C., Facer, B.A., Fields, R., Fischer, S.R., Fliss, T.P., Frensley, C., Gates, S.N., Glattfelder, K.J., Halverson, K.R. Hart, M.R., Hohmann, J.G., Howell, M.P., Jeung, D.P., Johnson, R.A., Karr, P.T., Kawal, R., Kidney, J.M., Knapik, R.H., Kuan, C.L., Lake, J.H., Laramee, A.R., Larsen, K.D., Lau, C., Lemon, T.A., Liang, A.J., Liu, Y., Luong, L.T., Michaels, J., Morgan, J.J., Morgan, R.J., Mortrud, M.T., Mosqueda, N.F., Ng, L.L., Ng, R., Orta, G.J., Overly, C.C., Pak, T.H., Parry, S.E., Pathak, S.D., Pearson, O.C., Puchalski, R.B., Riley, Z.L., Rockett, H.R., Rowland, S.A., Royall, J.J., Ruiz, M.J., Sarno, N.R., Schaffnit, K., Shapovalova, N.V., Sivisay, T., Slaughterbeck, C.R., Smith, S.C., Smith, K.A., Smith, B.I., Sodt, A.J., Stewart, N.N., Stumpf, K.R., Sunkin, S.M., Sutram, M., Tam, A., Teemer, C.D., Thaller, C., Thompson, C.L., Varnam, L.R., Visel, A., Whitlock, R.M., Wohnoutka, P.E., Wolkey, C.K., Wong, V.Y., Wood, M., Yaylaoglu, M.B., Young, R.C., Youngstrom, B.L., Yuan, X.F. Zhang, B., Zwingman, T.A., Jones, A.R., 2007. Genome-wide atlas of gene expression in the adult mouse brain. Nature 445, 168-176.

Lessmann, V., Heumann, R., 1998. Modulation of unitary glutamatergic synapses by neurotrophin-4/5 or brain-derived neurotrophic factor in hippocampal microcultures: presynaptic enhancement depends on pre-established paired-pulse facilitation. Neuroscience 86, 399-413.

Levine, E.S., Crozier, R.A., Black, I.B., Plummer, M.R., 1998. Brain-derived neurotrophic factor modulates hippocampal synaptic transmission by increasing Nmethyl-D-aspartic acid receptor activity. Proc. Natl. Acad. Sci. U. S. A. 95, 1023510239

Levine, E.S., Kolb, J.E., 2000. Brain-derived neurotrophic factor increases activity of NR2B-containing N-methyl-D-aspartate receptors in excised patches from hippocampal neurons. J. Neurosci. Res. 62, 357-362.

Li, Y.X., Zhang, Y., Lester, H.A., Schuman, E.M., Davidson, N., 1998. Enhancement of neurotransmitter release induced by brain-derived neurotrophic factor in cultured hippocampal neurons. J. Neurosci. 18, 10231-10240.

Liao, L., Pilotte, J., Xu, T., Wong, C.C., Edelman, G.M., Vanderklish, P., Yates 3rd, J.R., 2007. BDNF induces widespread changes in synaptic protein content and up- regulates components of the translation machinery: an analysis using highthroughput proteomics. J. Proteome Res. 6, 1059-1071.

Lin, A.C., Holt, C.E., 2007. Local translation and directional steering in axons. EMBO J $26,3729-3736$

Lin, S.Y., Wu, K., Levine, E.S., Mount, H.T., Suen, P.C., Black, I.B., 1998. BDNF acutely increases tyrosine phosphorylation of the NMDA receptor subunit 2B in cortical and hippocampal postsynaptic densities. Brain Res. Mol. Brain Res. 55, 20-27.

Link, W., Konietzko, U., Kauselmann, G., Krug, M., Schwanke, B., Frey, U., Kuhl, D. 1995. Somatodendritic expression of an immediate early gene is regulated by synaptic activity. Proc. Natl. Acad. Sci. U. S. A. 92, 5734-5738.

Linnarsson, S., Bjorklund, A., Ernfors, P., 1997. Learning deficit in BDNF mutant mice. Eur. J. Neurosci. 9, 2581-2587.

Lisman, J., Yasuda, R., Raghavachari, S., 2012. Mechanisms of CaMKII action in longterm potentiation. Nat. Rev. Neurosci. 13, 169-182.

Lu, Y., Christian, K., Lu, B., 2008. BDNF: a key regulator for protein synthesisdependent LTP and long-term memory? Neurobiol. Learn. Mem. 89, 312323.

Lugli, G., Larson, J., Demars, M.P., Smalheiser, N.R., 2012. Primary microRNA precursor transcripts are localized at post-synaptic densities in adult mouse forebrain. J. Neurochem. 123, 459-466.

Luo, L., 2000. Rho GTPases in neuronal morphogenesis. Nat. Rev. Neurosci. 1, 173 180.

Macchi, P., Kroening, S., Palacios, I.M., Baldassa, S., Grunewald, B., Ambrosino, C., Goetze, B., Lupas, A., St Johnston, D., Kiebler, M., 2003. Barentsz, a new component of the Staufen-containing ribonucleoprotein particles in mammalian cells, interacts with Staufen in an RNA-dependent manner. J. Neurosci. 23, 5778-5788.

Malenka, R.C., Bear, M.F., 2004. LTP and LTD: an embarrassment of riches. Neuron $44,5-21$.

Manadas, B., Santos, A.R., Szabadfi, K., Gomes, J.R., Garbis, S.D., Fountoulakis, M. Duarte, C.B., 2009. BDNF-induced changes in the expression of the translation machinery in hippocampal neurons: protein levels and dendritic mRNA J. Proteome Res. 8, 4536-4552.

Marin, P., Nastiuk, K.L., Daniel, N., Girault, J.A., Czernik, A.J., Glowinski, J., Nairn, A.C. Premont, J., 1997. Glutamate-dependent phosphorylation of elongation factor-2 and inhibition of protein synthesis in neurons. J. Neurosci. 17, 3445-3454.

Martin, K.C., Ephrussi, A., 2009. mRNA localization: gene expression in the spatial dimension. Cell 136, 719-730.

Mayford, M., Baranes, D., Podsypanina, K., Kandel, E.R., 1996. The 3'-untranslated region of CaMKII alpha is a cis-acting signal for the localization and translation of mRNA in dendrites. Proc. Natl. Acad. Sci. U. S. A. 93, 13250-13255.

Mayford, M., Siegelbaum, S.A., Kandel, E.R., 2012. Synapses and memory storage. Cold Spring Harb. Perspect. Biol. 4, pii: a005751.

Mellios, N., Sugihara, H., Castro, J., Banerjee, A., Le, C., Kumar, A., Crawford, B., Strathmann, J., Tropea, D., Levine, S.S., Edbauer, D., Sur, M., 2011. miR-132, an experience-dependent microRNA, is essential for visual cortex plasticity. Nat. Neurosci. 14, 1240-1242.

Melo, C.V., Mele, M., Curcio, M., Comprido, D., Silva, C.G., Duarte, C.B., 2013. BDNF regulates the expression and distribution of vesicular glutamate transporters in cultured hippocampal neurons. PLoS One 8, e53793.

Messaoudi, E., Bardsen, K., Srebro, B., Bramham, C.R., 1998. Acute intrahippocampal infusion of BDNF induces lasting potentiation of synaptic transmission in the rat dentate gyrus. J. Neurophysiol. 79, 496-499.

Messaoudi, E., Kanhema, T., Soule, J., Tiron, A., Dagyte, G., da Silva, B., Bramham, C.R. 2007. Sustained Arc/Arg3.1 synthesis controls long-term potentiation consolidation through regulation of local actin polymerization in the dentate gyrus in vivo. J. Neurosci. 27, 10445-10455.

Messaoudi, E., Ying, S.W., Kanhema, T., Croll, S.D., Bramham, C.R., 2002. Brainderived neurotrophic factor triggers transcription-dependent, late phase longterm potentiation in vivo. J. Neurosci. 22, 7453-7461.

Mikl, M., Vendra, G., Kiebler, M.A., 2011. Independent localization of MAP2 CaMKIIalpha and beta-actin RNAs in low copy numbers. EMBO Rep. 12, 10771084

Miller, S., Yasuda, M., Coats, J.K., Jones, Y., Martone, M.E., Mayford, M., 2002. Disruption of dendritic translation of CaMKIIalpha impairs stabilization of synaptic plasticity and memory consolidation. Neuron 36, 507-519.

Minichiello, L., 2009. TrkB signalling pathways in LTP and learning. Nat. Rev. Neurosci. $10,850-860$.

Minichiello, L., Calella, A.M., Medina, D.L., Bonhoeffer, T., Klein, R., Korte, M., 2002. Mechanism of TrkB-mediated hippocampal long-term potentiation. Neuron 36 , $121-137$.

Minichiello, L, Korte, M., Wolfer, D., Kuhn, R, Unsicker, K, Cestari, V, RossiArnaud, C., Lipp, H.P., Bonhoeffer, T., Klein, R., 1999. Essential role for TrkB receptors in hippocampus-mediated learning. Neuron 24, 401-414.

Mori, Y., Imaizumi, K., Katayama, T., Yoneda, T., Tohyama, M., 2000. Two cis-acting elements in the 3' untranslated region of alpha-CaMKII regulate its dendritic targeting. Nat. Neurosci. 3, 1079-1084.

Muddashetty, R.S., Kelic, S., Gross, C., Xu, M., Bassell, G.J., 2007. Dysregulated metabotropic glutamate receptor-dependent translation of AMPA receptor and postsynaptic density-95 mRNAs at synapses in a mouse model of fragile $X$ syndrome. J. Neurosci. 27, 5338-5348.

Muddashetty, R.S., Nalavadi, V.C., Gross, C., Yao, X., Xing, L., Laur, O., Warren, S.T. Bassell, G.J., 2011. Reversible inhibition of PSD-95 mRNA translation by miR125a, FMRP phosphorylation, and mGluR signaling. Mol. Cell. 42, 673-688. 
Munro, T.P., Magee, R.J., Kidd, G.J., Carson, J.H., Barbarese, E., Smith, L.M., Smith, R., 1999. Mutational analysis of a heterogeneous nuclear ribonucleoprotein A2 response element for RNA trafficking. J. Biol. Chem. 274, 34389-34395.

Muslimov, I.A., Iacoangeli, A., Brosius, J., Tiedge, H., 2006. Spatial codes in dendritic BC1 RNA. J. Cell. Biol. 175, 427-439.

Muslimov, I.A., Patel, M.V., Rose, A., Tiedge, H., 2011. Spatial code recognition in neuronal RNA targeting: role of RNA-hnRNP A2 interactions. J. Cell. Biol. 194, $441-457$.

Nairn, A.C., Palfrey, H.C., 1987. Identification of the major Mr 100,000 substrate for calmodulin-dependent protein kinase III in mammalian cells as elongation factor-2. J. Biol. Chem. 262, 17299-17303.

Nakata, H., Nakamura, S., 2007. Brain-derived neurotrophic factor regulates AMPA receptor trafficking to post-synaptic densities via IP3R and TRPC calcium signaling. FEBS Lett. 581, 2047-2054.

Napoli, I., Mercaldo, V., Boyl, P.P., Eleuteri, B., Zalfa, F., De Rubeis, S., Di Marino, D. Mohr, E., Massimi, M., Falconi, M., Witke, W., Costa-Mattioli, M., Sonenberg, N., Achsel, T., Bagni, C., 2008. The fragile $\mathrm{X}$ syndrome protein represses activitydependent translation through CYFIP1, a new 4E-BP. Cell 134, 1042-1054

Narisawa-Saito, M., Carnahan, J., Araki, K., Yamaguchi, T., Nawa, H., 1999. Brainderived neurotrophic factor regulates the expression of AMPA receptor proteins in neocortical neurons. Neuroscience 88, 1009-1014.

Ninan, I., Bath, K.G., Dagar, K., Perez-Castro, R., Plummer, M.R., Lee, F.S., Chao, M.V. 2010. The BDNF Val66Met polymorphism impairs NMDA receptor-dependent synaptic plasticity in the hippocampus. J. Neurosci. 30, 8866-8870.

Nudelman, A.S., DiRocco, D.P., Lambert, T.J., Garelick, M.G., Le, J., Nathanson, N.M., Storm, D.R., 2010. Neuronal activity rapidly induces transcription of the CREBregulated microRNA-132, in vivo. Hippocampus 20, 492-498.

Oe, S., Yoneda, Y., 2010. Cytoplasmic polyadenylation element-like sequences are involved in dendritic targeting of BDNF mRNA in hippocampal neurons. FEBS Lett. 584, 3424-3430.

Okada, Y., Yamazaki, H., Sekine-Aizawa, Y., Hirokawa, N., 1995. The neuron-specific kinesin superfamily protein KIF1A is a unique monomeric motor for anterograde axonal transport of synaptic vesicle precursors. Cell 81, 769-780.

Oleynikov, Y., Singer, R.H., 2003. Real-time visualization of ZBP1 association with beta-actin mRNA during transcription and localization. Curr. Biol. 13, 199-207.

Ouyang, Y., Rosenstein, A., Kreiman, G., Schuman, E.M., Kennedy, M.B., 1999. Tetanic stimulation leads to increased accumulation of $\mathrm{Ca}^{2+} /$ calmodulin-dependent protein kinase II via dendritic protein synthesis in hippocampal neurons. J. Neurosci. 19, 7823-7833.

Pal, R., Agbas, A., Bao, X., Hui, D., Leary, C., Hunt, J., Naniwadekar, A., Michaelis, M.L. Kumar, K.N., Michaelis, E.K., 2003. Selective dendrite-targeting of mRNAs of NR1 splice variants without exon 5: identification of a cis-acting sequence and isolation of sequence-binding proteins. Brain Res. 994, 1-18.

Pan, F., Huttelmaier, S., Singer, R.H., Gu, W., 2007. ZBP2 facilitates binding of ZBP1 to beta-actin mRNA during transcription. Mol. Cell. Biol. 27, 8340-8351.

Park, H., Poo, M., 2013. Neurotrophin regulation of neural circuit development and function. Nat. Rev. Neurosci. 14, 7-23.

Park, S., Park, J.M., Kim, S., Kim, J.A., Shepherd, J.D., Smith-Hicks, C.L., Chowdhury, S Kaufmann, W., Kuhl, D., Ryazanov, A.G., Huganir, R.L., Linden, D.J., Worley, P.F., 2008. Elongation factor 2 and fragile $X$ mental retardation protein control the dynamic translation of Arc/Arg3.1 essential for mGluR-LTD. Neuron 59, 70-83.

Pascual, M., Climent, E., Guerri, C., 2001. BDNF induces glutamate release in cerebrocortical nerve terminals and in cortical astrocytes. Neuroreport 12, $2673-$ 2677.

Patterson, S.L., Abel, T., Deuel, T.A., Martin, K.C., Rose, J.C., Kandel, E.R., 1996. Recombinant BDNF rescues deficits in basal synaptic transmission and hippocampal LTP in BDNF knockout mice. Neuron 16, 1137-1145.

Pereira, D.B., Rebola, N., Rodrigues, R.J., Cunha, R.A., Carvalho, A.P., Duarte, C.B., 2006. Trkb receptors modulation of glutamate release is limited to a subset of nerve terminals in the adult rat hippocampus. J. Neurosci. Res. 83, 832-844.

Perycz, M., Urbanska, A.S., Krawczyk, P.S., Parobczak, K., Jaworski, J., 2011. Zipcode binding protein 1 regulates the development of dendritic arbors in hippocampal neurons. J. Neurosci. 31, 5271-5285.

Pestova, T.V., Lorsch, J.R., Hellen, C.U.T., 2007. The mechanism of translation initiation in eukaryotes. In: Mathews, M.B., Sonenberg, N., Hershey, J.W.B. (Eds.) Translational Control in Biology and Medicine. Cold Spring Harbor Laboratory Press, Cold Spring Harbor, New York, pp. 87-128.

Poon, M.M., Choi, S.H., Jamieson, C.A., Geschwind, D.H., Martin, K.C., 2006. Identification of process-localized mRNAs from cultured rodent hippocampal neurons. J. Neurosci. 26, 13390-13399.

Pozzo-Miller, L.D., Gottschalk, W., Zhang, L., McDermott, K., Du, J. Gopalakrishnan, R., Oho, C., Sheng, Z.H., Lu, B., 1999. Impairments in highfrequency transmission, synaptic vesicle docking, and synaptic protein distribution in the hippocampus of BDNF knockout mice. J. Neurosci. 19, 4972-4983.

Rao, V.R., Pintchovski, S.A., Chin, J., Peebles, C.L., Mitra, S., Finkbeiner, S., 2006. AMPA receptors regulate transcription of the plasticity-related immediate-early gene Arc. Nat. Neurosci. 9, 887-895.

Redondo, R.L., Morris, R.G., 2011. Making memories last: the synaptic tagging and capture hypothesis. Nat. Rev. Neurosci. 12, 17-30.

Rehbein, M., Wege, K., Buck, F., Schweizer, M., Richter, D., Kindler, S., 2002. Molecular characterization of MARTA1, a protein interacting with the dendritic targeting element of MAP2 mRNAs. J. Neurochem. 82, 1039-1046.

Remenyi, J., Hunter, C.J., Cole, C., Ando, H., Impey, S., Monk, C.E., Martin, K.J. Barton, G.J., Hutvagner, G., Arthur, J.S., 2010. Regulation of the miR-212/132 locus by MSK1 and CREB in response to neurotrophins. Biochem. J. 428, 281-291.

Rex, C.S., Lin, C.Y., Kramar, E.A., Chen, L.Y., Gall, C.M., Lynch, G., 2007. Brain-derived neurotrophic factor promotes long-term potentiation-related cytoskeletal changes in adult hippocampus. J. Neurosci. 27, 3017-3029.

Rhoads, R.E., 1999. Signal transduction pathways that regulate eukaryotic protein synthesis. J. Biol. Chem. 274, 30337-30340.

Richter, J.D., 2007. CPEB: a life in translation. Trends Biochem. Sci. 32, 279-285.

Righi, M., Tongiorgi, E., Cattaneo, A., 2000. Brain-derived neurotrophic factor (BDNF) induces dendritic targeting of BDNF and tyrosine kinase B mRNAs in hippocampal neurons through a phosphatidylinositol-3 kinase-dependent pathway. J. Neurosci. 20, 3165-3174.

Ross, A.F., Oleynikov, Y., Kislauskis, E.H. Taneja, K.L., Singer, R.H., 1997. Characterization of a beta-actin mRNA zipcode-binding protein. Mol. Cell. Biol. 17, 21582165.

Ryazanov, A.G., Rudkin, B.B., Spirin, A.S., 1991. Regulation of protein synthesis at the elongation stage. New insights into the control of gene expression in eukaryotes. FEBS Lett. 285, 170-175.

Ryazanov, A.G., Shestakova, E.A., Natapov, P.G., 1988. Phosphorylation of elongation factor 2 by EF-2 kinase affects rate of translation. Nature 334, 170-173.

Santos, A.R., Comprido, D., Duarte, C.B., 2010. Regulation of local translation at the synapse by BDNF. Prog. Neurobiol. 92, 505-516.

Sasaki, Y., Welshhans, K., Wen, Z., Yao, J., Xu, M., Goshima, Y., Zheng, J.Q., Bassell, G.J., 2010. Phosphorylation of zipcode binding protein 1 is required for brainderived neurotrophic factor signaling of local beta-actin synthesis and growth cone turning. J. Neurosci. 30, 9349-9358.

Scheetz, A.J., Nairn, A.C., Constantine-Paton, M., 2000. NMDA receptor-mediated control of protein synthesis at developing synapses. Nat. Neurosci. 3, 211216.

Schinder, A.F., Berninger, B., Poo, M., 2000. Postsynaptic target specificity of neurotrophin-induced presynaptic potentiation. Neuron 25, 151-163.

Schratt, G.M., Nigh, E.A., Chen, W.G., Hu, L., Greenberg, M.E., 2004. BDNF regulates the translation of a select group of mRNAs by a mammalian target of rapamycin-phosphatidylinositol 3-kinase-dependent pathway during neuronal development. J. Neurosci. 24, 7366-7377.

Schratt, G.M., Tuebing, F., Nigh, E.A., Kane, C.G., Sabatini, M.E., Kiebler, M., Greenberg, M.E., 2006. A brain-specific microRNA regulates dendritic spine development. Nature 439, 283-289.

Shiina, N., Shinkura, K., Tokunaga, M., 2005. A novel RNA-binding protein in neuronal RNA granules: regulatory machinery for local translation. J. Neurosci. 25, 4420-4434.

Shiina, N., Yamaguchi, K., Tokunaga, M., 2010. RNG105 deficiency impairs the dendritic localization of mRNAs for $\mathrm{Na}^{+} / \mathrm{K}^{+}$ATPase subunit isoforms and leads to the degeneration of neuronal networks. J. Neurosci. 30,12816-12830.

Simsek-Duran, F., Lonart, G., 2008. The role of RIM1alpha in BDNF-enhanced glutamate release. Neuropharmacology 55, 27-34.

Small, D.L., Murray, C.L., Mealing, G.A., Poulter, M.O., Buchan, A.M., Morley, P., 1998. Brain derived neurotrophic factor induction of N-methyl-D-aspartate receptor subunit NR2A expression in cultured rat cortical neurons. Neurosci. Lett. 252, $211-214$.

Steward, O., Levy, W.B., 1982. Preferential localization of polyribosomes under the base of dendritic spines in granule cells of the dentate gyrus. J. Neurosci. 2 284-291.

Steward, O., Wallace, C.S., Lyford, G.L., Worley, P.F., 1998. Synaptic activation causes the mRNA for the IEG Arc to localize selectively near activated postsynaptic sites on dendrites. Neuron 21, 741-751.

Steward, O., Worley, P.F., 2001. Selective targeting of newly synthesized Arc mRNA to active synapses requires NMDA receptor activation. Neuron 30, 227-240.

Subramanian, M., Rage, F., Tabet, R., Flatter, E., Mandel, J.L., Moine, H., 2011. Gquadruplex RNA structure as a signal for neurite mRNA targeting. EMBO Rep. 12, 697-704.

Suen, P.C., Wu, K., Levine, E.S., Mount, H.T. Xu, J.L., Lin, S.Y., Black, I.B., 1997. Brainderived neurotrophic factor rapidly enhances phosphorylation of the postsynaptic N-methyl-D-aspartate receptor subunit 1. Proc. Natl. Acad. Sci. U. S. A. $94,8191-8195$.

Takei, N., Inamura, N., Kawamura, M., Namba, H., Hara, K., Yonezawa, K., Nawa, H., 2004. Brain-derived neurotrophic factor induces mammalian target of rapamycin-dependent local activation of translation machinery and protein synthesis in neuronal dendrites. J. Neurosci. 24, 9760-9769.

Takei, N., Kawamura, M., Hara, K., Yonezawa, K., Nawa, H., 2001. Brain-derived neurotrophic factor enhances neuronal translation by activating multiple initiation processes: comparison with the effects of insulin. J. Biol. Chem. 276, 42818-42825.

Takei, N., Kawamura, M., Ishizuka, Y., Kakiya, N., Inamura, N., Namba, H., Nawa, H., 2009. Brain-derived neurotrophic factor enhances the basal rate of protein synthesis by increasing active eukaryotic elongation factor 2 levels and promoting translation elongation in cortical neurons. J. Biol. Chem. 284, 2634026348 .

Tanaka, J., Horiike, Y., Matsuzaki, M., Miyazaki, T., Ellis-Davies, G.C., Kasai, H., 2008 Protein synthesis and neurotrophin-dependent structural plasticity of single dendritic spines. Science 319, 1683-1687.

Tang, S.J., Meulemans, D., Vazquez, L., Colaco, N., Schuman, E., 2001. A role for a rat homolog of staufen in the transport of RNA to neuronal dendrites. Neuron 32, 463-475. 
Tang, S.J., Reis, G., Kang, H., Gingras, A.C., Sonenberg, N., Schuman, E.M., 2002. A rapamycin-sensitive signaling pathway contributes to long-term synaptic plasticity in the hippocampus. Proc. Natl. Acad. Sci. U. S. A. 99, 467-472.

Tartaglia, N., Du, J., Tyler, W.J., Neale, E., Pozzo-Miller, L., Lu, B., 2001. Protein synthesis-dependent and -independent regulation of hippocampal synapses by brain-derived neurotrophic factor. J. Biol. Chem. 276, 37585-37593.

Taylor, D.J., Frank, J., Kinzy, T.G., 2007. Structure and function of the eukaryotic ribosome and elongation factors. In: Mathews, M.B., Sonenberg, N., Hershey, J.W.B. (Eds.), Translational Control in Biology and Medicine. Cold Spring Harbor Laboratory Press, Cold Spring Harbor, New York, pp. 59-85.

Thakker-Varia, S., Alder, J., Crozier, R.A., Plummer, M.R., Black, I.B., 2001. Rab3A is required for brain-derived neurotrophic factor-induced synaptic plasticity: transcriptional analysis at the population and single-cell levels. J. Neurosci. 21, 6782-6790

Timmusk, T., Palm, K., Metsis, M., Reintam, T., Paalme, V., Saarma, M., Persson, H., 1993. Multiple promoters direct tissue-specific expression of the rat BDNF gene. Neuron 10, 475-489.

Tiruchinapalli, D.M., Oleynikov, Y., Kelic, S., Shenoy, S.M., Hartley, A., Stanton, P.K., Singer, R.H., Bassell, G.J., 2003. Activity-dependent trafficking and dynamic localization of zipcode binding protein 1 and beta-actin mRNA in dendrites and spines of hippocampal neurons. J. Neurosci. 23, 3251-3261.

Tognini, P., Putignano, E., Coatti, A., Pizzorusso, T., 2011. Experience-dependent expression of miR-132 regulates ocular dominance plasticity. Nat. Neurosci. 14, 1237-1239.

Troca-Marin, J.A., Alves-Sampaio, A., Tejedor, F.J., Montesinos, M.L., 2010. Local translation of dendritic RhoA revealed by an improved synaptoneurosome preparation. Mol. Cell. Neurosci. 43, 308-314.

Tubing, F., Vendra, G., Mikl, M., Macchi, P., Thomas, S., Kiebler, M.A., 2010. Dendritically localized transcripts are sorted into distinct ribonucleoprotein particles that display fast directional motility along dendrites of hippocampal neurons. J. Neurosci. 30, 4160-4170.

Tucker, R.P., Garner, C.C., Matus, A., 1989. In situ localization of microtubule-associated protein mRNA in the developing and adult rat brain. Neuron 2,1245-1256.

Tyler, W.J., Pozzo-Miller, L., 2003. Miniature synaptic transmission and BDNF modulate dendritic spine growth and form in rat CA1 neurones. J. Physiol. 553, 497-509.

Tyler, W.J., Pozzo-Miller, L.D., 2001. BDNF enhances quantal neurotransmitter release and increases the number of docked vesicles at the active zones of hippocampal excitatory synapses. J. Neurosci. 21, 4249-4258.

Tyler, W.J., Zhang, X.L., Hartman, K., Winterer, J., Muller, W., Stanton, P.K., PozzoMiller, L., 2006. BDNF increases release probability and the size of a rapidly recycling vesicle pool within rat hippocampal excitatory synapses. J. Physiol. 574, 787-803.

Udagawa, T., Swanger, S.A., Takeuchi, K., Kim, J.H., Nalavadi, V., Shin, J., Lorenz, L.J. Zukin, R.S., Bassell, G.J., Richter, J.D., 2012. Bidirectional control of mRNA translation and synaptic plasticity by the cytoplasmic polyadenylation complex. Mol. Cell. 47, 253-266.

Verpelli, C., Piccoli, G., Zibetti, C., Zanchi, A., Gardoni, F., Huang, K., Brambilla, D., Di Luca, M., Battaglioli, E., Sala, C., 2010. Synaptic activity controls dendritic spine morphology by modulating eEF2-dependent BDNF synthesis. J. Neurosci. 30, 5830-5842.

Vessey, J.P., Schoderboeck, L., Gingl, E., Luzi, E., Riefler, J., Di Leva, F., Karra, D. Thomas, S., Kiebler, M.A., Macchi, P., 2010. Mammalian Pumilio 2 regulates dendrite morphogenesis and synaptic function. Proc. Natl. Acad. Sci. U. S. A. 107, 3222-3227.

Vo, N., Klein, M.E., Varlamova, O., Keller, D.M., Yamamoto, T., Goodman, R.H., Impey, S., 2005. A cAMP-response element binding protein-induced microRNA regulates neuronal morphogenesis. Proc. Natl. Acad. Sci. U. S. A. 102, 16426-16431.
Watson, F.L., Heerssen, H.M., Bhattacharyya, A., Klesse, L., Lin, M.Z., Segal, R.A., 2001 Neurotrophins use the Erk5 pathway to mediate a retrograde survival response. Nat. Neurosci. 4, 981-988.

Weatherill, D.B., Dyer, J., Sossin, W.S., 2010. Ribosomal protein S6 kinase is a critica downstream effector of the target of rapamycin complex 1 for long-term facilitation in Aplysia. J. Biol. Chem. 285, 12255-12267.

Wibrand, K., Panja, D., Tiron, A., Ofte, M.L., Skaftnesmo, K.O., Lee, C.S., Pena, J.T., Tuschl, T., Bramham, C.R., 2010. Differential regulation of mature and precursor microRNA expression by NMDA and metabotropic glutamate receptor activation during LTP in the adult dentate gyrus in vivo. Eur. J. Neurosci. 31, 636-645.

Wu, Y.C., Williamson, R., Li, Z., Vicario, A., Xu, J., Kasai, M., Chern, Y., Tongiorgi, E. Baraban, J.M., 2011. Dendritic trafficking of brain-derived neurotrophic factor mRNA: regulation by translin-dependent and -independent mechanisms. J. Neurochem. 116, 1112-1121.

Xie, W., Zhang, K., Cui, B., 2012. Functional characterization and axonal transport of quantum dot labeled BDNF. Integr. Biol. 8, 953-960.

Xu, B., Gottschalk, W., Chow, A., Wilson, R.I., Schnell, E., Zang, K., Wang, D. Nicoll, R.A., Lu, B., Reichardt, L.F., 2000. The role of brain-derived neurotrophic factor receptors in the mature hippocampus: modulation of long-term potentiation through a presynaptic mechanism involving TrkB. J. Neurosci. 20, 68886897.

Yano, H., Ninan, I., Zhang, H., Milner, T.A., Arancio, O., Chao, M.V., 2006. BDNFmediated neurotransmission relies upon a myosin VI motor complex. Nat. Neurosci. 9, 1009-1018.

Ye, H., Kuruvilla, R., Zweifel, L.S., Ginty, D.D., 2003. Evidence in support of signaling endosome-based retrograde survival of sympathetic neurons. Neuron 39, 57-68.

Yin, Y., Edelman, G.M., Vanderklish, P.W., 2002. The brain-derived neurotrophic factor enhances synthesis of Arc in synaptoneurosomes. Proc. Natl. Acad. Sci. U. S. A. 99, 2368-2373.

Ying, S.W., Futter, M., Rosenblum, K., Webber, M.J., Hunt, S.P., Bliss, T.V., Bramham, C.R., 2002. Brain-derived neurotrophic factor induces long-term potentiation in intact adult hippocampus: requirement for ERK activation coupled to CREB and upregulation of Arc synthesis. J. Neurosci. 22, 15321540.

Yonekawa, Y., Harada, A., Okada, Y., Funakoshi, T., Kanai, Y., Takei, Y., Terada, S. Noda, T., Hirokawa, N., 1998. Defect in synaptic vesicle precursor transport and neuronal cell death in KIF1A motor protein-deficient mice. J. Cell. Biol. $141,431-441$.

Zadran, S., Jourdi, H., Rostamiani, K., Qin, Q., Bi, X., Baudry, M., 2010. Brain-derived neurotrophic factor and epidermal growth factor activate neuronal m-calpain via mitogen-activated protein kinase-dependent phosphorylation. J. Neurosci. 30, 1086-1095.

Zeitelhofer, M., Karra, D., Macchi, P., Tolino, M., Thomas, S., Schwarz, M., Kiebler, M. Dahm, R., 2008. Dynamic interaction between P-bodies and transport ribonucleoprotein particles in dendrites of mature hippocampal neurons. J. Neurosci. 28, 7555-7562.

Zhang, G., Neubert, T.A., Jordan, B.A., 2012. RNA binding proteins accumulate at the postsynaptic density with synaptic activity. J. Neurosci. 32, 599-609.

Zhang, H.L., Eom, T., Oleynikov, Y., Shenoy, S.M., Liebelt, D.A., Dictenberg, J.B. Singer, R.H., Bassell, G.J., 2001. Neurotrophin-induced transport of a beta-actin mRNP complex increases beta-actin levels and stimulates growth cone motility. Neuron 31, 261-275.

Zheng, F., Luo, Y., Wang, H., 2009. Regulation of brain-derived neurotrophic factormediated transcription of the immediate early gene Arc by intracellular calcium and calmodulin. J. Neurosci. Res. 87, 380-392.

Zhong, J., Zhang, T., Bloch, L.M., 2006. Dendritic mRNAs encode diversified functionalities in hippocampal pyramidal neurons. BMC Neurosci. 7, 17. 